\title{
Break-crop effects on wheat production across soils and seasons in a semi-arid environment
}

\author{
T. M. McBeath ${ }^{\mathrm{A}, \mathrm{D}}$, V. V. S. R. Gupta ${ }^{\mathrm{A}}$, R. S. Llewellyn ${ }^{\mathrm{A}}$, C. W. Davoren ${ }^{\mathrm{A}}$, \\ and A. M. Whitbread ${ }^{\mathrm{A}, \mathrm{B}, \mathrm{C}}$ \\ ${ }^{A}$ CSIRO Agriculture Flagship, CSIRO Ecosystem Sciences, PMB 2, Glen Osmond, SA 5064, Australia. \\ ${ }^{B}$ Crop Production Systems in the Tropics, Georg-August-University Göttingen, Grisebachstr. 6, \\ D-37077, Göttingen, Germany. \\ C International Crops Research Institute for the Semi-Arid Tropics (ICRISAT), Patancheru, Telengana, India. \\ ${ }^{D}$ Corresponding author. Email: therese.mcbeath@csiro.au
}

\begin{abstract}
In low-rainfall environments, a high frequency of cereal crops has been favoured for optimising productivity and risk. However, cereals at high intensity often lead to declining water-use efficiency and increasing inputs to cope with emergent nutritional, disease and weed problems. The value of including breaks in the cropping sequence can involve a high level of uncertainty in low-rainfall areas where non-cereal crops are more risky and profitability is largely determined by the subsequent benefit to cereal productivity. In this study, we aimed to improve understanding of the magnitude and primary source of break benefits such as nutrition, water and disease management in a low-rainfall environment where a high level of within-field soil variability can also contribute to uncertainty about the value of breaks. In on-farm field experiments near Karoonda in the South Australian Mallee, breaks were grown in 2009 or 2010 on four distinct soil types across a dune-swale catena. The effect of these breaks on subsequent cereal production was measured for up to 3 years. In addition, the effect of breaks on nutrition and water available, along with disease infection in subsequent cereal crops, was explored and actual yields were compared with nitrogen and water-limited potential yields. Consistent cumulative benefits to subsequent cereal crops of at least $1 \mathrm{tha}^{-1}$ after 3 years accrue from breaks grown on the different soil types. The inclusion of breaks had beneficial effects on the cycling and supply of nutrients along with some short-term impacts on infection by Rhizoctonia solani AG8 in subsequent cereals, whereas there were no conclusive effects of breaks on the supply of water to subsequent crops. This study suggests that the inclusion of both legume and brassica breaks is likely to be beneficial to subsequent cereal production where nitrogen is a factor limiting productivity in low-rainfall, semi-arid environments.
\end{abstract}

Additional keywords: sequence, rotation, $\mathrm{N}$ mineralisation, $\mathrm{N}$ supply potential.

Received 19 June 2014, accepted 6 October 2014, published online 28 April 2015

\section{Introduction}

Intensive cropping in semi-arid Mallee environments can increase productivity compared with traditional cereal-volunteer pasture based rotations (Sadras 2002; Sadras and Roget 2004). Although cereal crops are considered the lowest risk crop choice in lowrainfall environments (Whitbread et al. 2015), farming systems that rely on continuous cereal cropping often present difficulties in managing pests, diseases or nutrition. Crop or pasture breaks can be used as an opportunistic tool in the sequence to manage these constraints (Díaz-Ambrona and Ines Minguez 2001). For example, the growth of Rhizoctonia solani AG8 fungus within a crop differs between crops, and the inoculum levels at harvest vary between cereal and non-cereal crops (Gupta et al. 2010). As a result, non-cereal crops in the sequence are likely to alter the impacts of disease on the following cereal crops (Rovira 1990). In addition, plant species can affect the composition and function of different groups of biota, influencing nutrient cycling to plants and the ability of pathogens to cause disease (Bowen and Rovira 1999; Gupta et al. 2011).

The magnitude of the benefit of breaks to continuous cereal cropping in Australia has been variable; however, benefits were observed in $90 \%$ of cases reviewed by Seymour et al. (2012), and Kirkegaard et al. (2008) found that these benefits resulted in $17-75 \%$ increases in subsequent cereal production. In another study largely reliant on results from higher rainfall regions, Angus et al. (2008) suggested that the break effect is a fixed amount of extra grain $\left(\mathrm{tha}^{-1}\right)$ rather than a proportion of wheat yield, with benefits in the range of $0.9-1.8 \mathrm{tha}^{-1}$ extra yield in the subsequent wheat crop depending on the break utilised. Seymour et al. (2012) found the benefit to be in the order of 0.3-0.6 tha $\mathrm{th}^{-1}$ in Western Australia. Although not often measured in field experiments, it is recognised that the decision to incorporate breaks on farm involves consideration of the short-term and longer term (2-3 years post-break) 
break effects (Angus et al. 2001; Kirkegaard et al. 2008; Roper et al. 2012; Kirkegaard and Ryan 2014).

A better understanding of the factors involved and the trigger points at which the benefits outweigh the risk of introducing the break need to be identified to support decisions to use break crops (Lawes and Renton 2010; Seymour et al. 2012). It is well recognised that break crops are riskier than cereals to grow, even in medium- and high-rainfall zones where there are more break crop options with good climate adaption (Kirkegaard et al. 2001; Seymour et al. 2012). In the low-rainfall environment, risk is further increased and there are fewer crop options. Sadras and Roget (2004) showed positive break effects with the use of canola and legumes in the Mallee environment, but profitability compared with continuous cereal largely depended on breaks being grown opportunistically when there was adequate early season rainfall and reduced risk of poor yield of the break crop (Whitbread et al. 2015).

As well as having low (and highly variable) rainfall $(<350 \mathrm{~mm}$ annual rainfall), the Mallee environment features dune-swale systems with soil types that vary considerably in production potential and within relatively small distances (Whitbread et al. 2008; Rab et al. 2009). For this reason, the use of within-paddock zoning and soil-specific management by farmers is common in the Mallee region (Robertson et al. 2012). Knowledge of the effect of soil type on break effects in Mallee environments is required to identify the best management of breaks according to the dominant soil type in a paddock. For example, the sandy soil types of the region are known to be nitrogen (N)-limited (Sadras 2002; Sadras and Roget 2004; Monjardino et al. 2013), and therefore the $\mathrm{N}$ contribution of any break is likely to be a key factor in determining break-crop inclusion on these soils. This may not be the case on heavier soils within the same paddock.

In this risky, low-rainfall environment with variable soils, and where cereal production is the dominant driver of farm profitability, the influence of breaks on subsequent crops is particularly important in break-crop decisions. The aim of this study is to improve understanding and confidence in the evaluation of breaks by identifying: $(i)$ the effect of different breaks on the production of subsequent wheat crops over a 3-year period; (ii) the components of the break effect that cause changes in wheat production; and (iii) the influence of soil type on break-crop productivity and break effects.

\section{Materials and methods}

\section{Site characteristics}

The experiments were set up on three key soil types in the same field at Lowaldie ( $\left.33^{\circ} 59.616 \mathrm{~S}, 136^{\circ} 19.915 \mathrm{E}\right), 20 \mathrm{~km}$ north-east of Karoonda, South Australia. Depending on the location within the toposequence, the soil types were a deep sand (Kandosol, dune and crest), a sand over clay loam (Calcarosol, mid-slope) and a clay loam over clay (Chromosol, swale), classified according to the Australian Soil Classification (Isbell 1997).

Soil plant-available water (PAW) capacity and bulk density were characterised at each site to $1 \mathrm{~m}$ depth using the methods of Dalgliesh and Foale (1998). The soils were analysed for a range of chemical properties that control soil fertility. Soil $\mathrm{pH}$ and electrical conductivity (EC) were measured in a $1: 5$ soil: water suspension (Rayment and Lyons 2011). Boron concentration was determined by hot calcium chloride extraction (Rayment and Lyons 2011). Exchangeable sodium percentage (ESP) was calculated following measurement of cation exchange capacity (CEC) using $0.1 \mathrm{M}$ ammonium chloride with $0.1 \mathrm{~m}$ barium chloride extractant (Method 15E1; Rayment and Lyons 2011). Organic carbon (C) was measured according to the Walkley-Black method (Walkley and Black 1934; Rayment and Lyons 2011). Topsoil samples (0-0.1 m depth) were also analysed for Colwell extractable phosphorus (P) and potassium (K) (Colwell 1963; Rayment and Lyons 2011), extractable sulfur using $0.25 \mathrm{~m}$ potassium chloride at $40^{\circ} \mathrm{C}$ (Blair et al. 1991), and water repellence using the waterdroplet test described by King (1981). In 2009 prior to implementing the treatments, surface $(0-0.1 \mathrm{~m})$ soils were analysed for disease risk using the DNA-based method for soil-borne diseases (Ophel-Keller et al. 2008).

Although the four soil types tested in this experiment are in the same field, they have very different properties. The dune is neutral $\mathrm{pH}$ sand, alkaline at depth with low organic $\mathrm{C}$ and $\mathrm{CEC}$ but with adequate levels of extractable topsoil $\mathrm{P}$ and $\mathrm{K}$ (Tables 1 and 2). This soil does not appear to be constrained by boron $\left(<15 \mathrm{mg} \mathrm{kg}^{-1}\right)$, salinity $\left(\mathrm{EC}<0.9 \mathrm{dS} \mathrm{m}^{-1}\right)$ or exchangeable sodium (ESP $<6 \%$ ) at depth, according to critical values given in Peverill et al. (1999). Different crop types differ in their response to soil constraints (Nuttall and Armstrong 2010), and the thresholds used here do not include the range in tolerance of the crop types to constraints. The crest has very similar properties to the dune but has heavier texture below $0.4-0.6 \mathrm{~m}$ depth and a much smaller PAW capacity (Tables 1 and 2). The dune and crest have markedly higher surface water repellency than the midslope and swale (Table 1). The mid-slope has a neutral surface and is alkaline at depth, with ESP likely to constrain crop productivity from $0.4 \mathrm{~m}$, and boron and $\mathrm{pH}$ from $0.8 \mathrm{~m}$ (Table 2). The swale also has a neutral surface and is alkaline at depth with exchangeable sodium and boron constraints from $0.4 \mathrm{~m}$, and possibly salinity constraints from $0.8 \mathrm{~m}$ (Table 2). Results from the analysis of the surface $(0-0.1 \mathrm{~m})$ soils from the experimental site at the start of the experiment, in 2009, indicated disease risk for rhizoctonia root rot only, with $R$. solani AG8 inoculum levels in the medium-high disease-risk category (Ophel-Keller et al. 2008).

The climate at this site is Mediterranean with winterdominant rainfall; annual average rainfall is $337 \mathrm{~mm}$ and

Table 1. Soil surface (0-0.1 m) characteristics \pm standard deviation of the dune, crest, mid-slope and swale measured before sowing of crops in 2009

CEC, Cation exchange capacity

\begin{tabular}{lccccr}
\hline Soil & $\begin{array}{c}\text { Water } \\
\text { repellency (s) }\end{array}$ & $\begin{array}{c}\text { Colwell P } \\
\left(\mathrm{mg} \mathrm{kg}^{-1}\right)\end{array}$ & $\begin{array}{c}\text { Colwell K } \\
\left(\mathrm{mg} \mathrm{kg}^{-1}\right)\end{array}$ & $\begin{array}{c}\text { Sulfur } \\
\mathrm{KCl}-40 \\
\left(\mathrm{mg} \mathrm{kg}^{-1}\right)\end{array}$ & $\begin{array}{c}\mathrm{CEC} \\
\left(\mathrm{cmol} \mathrm{kg}^{-1}\right)\end{array}$ \\
\hline Dune & $353 \pm 137$ & $26 \pm 6$ & $111 \pm 23$ & $1.7 \pm 0.4$ & $2.4 \pm 0.6$ \\
Crest & $123 \pm 71$ & $23 \pm 4$ & $114 \pm 9$ & $2.2 \pm 0.7$ & $2.8 \pm 0.2$ \\
Mid-slope & $16 \pm 5$ & $30 \pm 3$ & $149 \pm 26$ & $3.0 \pm 0.8$ & $3.2 \pm 0.2$ \\
Swale & $4 \pm 4$ & $46 \pm 12$ & $457 \pm 50$ & $3.9 \pm 0.6$ & $14.7 \pm 3.3$ \\
\hline
\end{tabular}


average April-October growing season rainfall $237 \mathrm{~mm}$. The 2009 growing season had average rainfall $(224 \mathrm{~mm}), 2010 \mathrm{had}$ above-average growing season rainfall $(342 \mathrm{~mm}), 2011 \mathrm{had}$ below-average growing season rainfall $(203 \mathrm{~mm})$ but aboveaverage annual rainfall $(505 \mathrm{~mm})$ due to record summer rainfall events, and 2012 was an average growing season (258 mm) with a dry finish.

Before the experimental treatments were implemented in 2009, the paddock was sown to wheat (Triticum aestivum) in
2008, triticale ( $\times$ Triticosecale) in 2007, barley (Hordeum vulgare) in 2006, volunteer medic-based pasture in 2005, wheat in 2004 and volunteer medic-based pasture in 2003 and 2002.

\section{Experimental design}

A winter crop was sown in May of each season from 2009 to 2012 following opening rains of at least $20 \mathrm{~mm}$ (Table 3). All crops were sown with a 7-row conventional plot seeder with narrow

Table 2. Soil profile chemical and physical characteristics \pm standard deviation of the dune, crest, mid-slope and swale measured before sowing of crops in 2009

BD, Bulk density; CLL, crop lower limit; DUL, drained upper limit; ESP, exchangeable sodium percentage; EC, electrical conductivity (EC and $\mathrm{pH}$ determined in $1: 5$ soil: water); OC, organic carbon; b.d., below detection

\begin{tabular}{|c|c|c|c|c|c|c|c|c|}
\hline $\begin{array}{l}\text { Depth } \\
\text { (m) }\end{array}$ & $\begin{array}{c}\mathrm{BD} \\
\left(\mathrm{g} \mathrm{cm}^{-3}\right)\end{array}$ & CLL & $(\mathrm{v} / \mathrm{v}){ }^{\text {DUL }}$ & $\begin{array}{l}\text { ESP } \\
(\%)\end{array}$ & $\begin{array}{c}\text { Boron } \\
\left(\mathrm{mg} \mathrm{kg}^{-1}\right)\end{array}$ & $\begin{array}{c}\mathrm{EC} \\
\left(\mathrm{dS} \mathrm{m}^{-1}\right)\end{array}$ & $\begin{array}{c}\mathrm{pH} \\
\left(\mathrm{H}_{2} \mathrm{O}\right)\end{array}$ & $\begin{array}{l}\text { OC } \\
(\%)\end{array}$ \\
\hline \multicolumn{9}{|c|}{ Dune } \\
\hline $0-0.1$ & 1.57 & 0.01 & 0.09 & $0.8 \pm 0.1$ & $0.3 \pm 0.01$ & $0.03 \pm 0.005$ & $6.5 \pm 0.3$ & 0.80 \\
\hline $0.1-0.2$ & 1.70 & 0.04 & 0.12 & $0.8 \pm 0.5$ & $0.3 \pm 0.06$ & $0.02 \pm 0.005$ & $6.6 \pm 0.3$ & 0.46 \\
\hline $0.2-0.4$ & 1.74 & 0.08 & 0.13 & $0.9 \pm 0.5$ & $0.4 \pm 0.09$ & $0.02 \pm 0.004$ & $6.9 \pm 0.2$ & 0.22 \\
\hline $0.4-0.6$ & 1.83 & 0.08 & 0.10 & $1.9 \pm 1.9$ & $0.8 \pm 0.4$ & $0.06 \pm 0.03$ & $8.7 \pm 0.2$ & 0.60 \\
\hline $0.6-0.8$ & 1.47 & 0.09 & 0.14 & $5.6 \pm 3.6$ & $2.4 \pm 0.7$ & $0.09 \pm 0.03$ & $9.2 \pm 0.2$ & \\
\hline $0.8-1.0$ & 1.47 & 0.12 & 0.12 & $5.6 \pm 3.6$ & $2.4 \pm 0.7$ & $0.09 \pm 0.03$ & $9.2 \pm 0.2$ & \\
\hline \multicolumn{9}{|c|}{ Crest } \\
\hline $0-0.1$ & 1.58 & 0.01 & 0.07 & $0.9 \pm 0.2$ & $0.4 \pm 0.09$ & $0.03 \pm 0.01$ & $6.8 \pm 0.5$ & 0.42 \\
\hline $0.1-0.2$ & 1.58 & 0.03 & 0.08 & $1.2 \pm 0.3$ & $0.3 \pm 0.07$ & $0.03 \pm 0.009$ & $6.8 \pm 0.5$ & 0.20 \\
\hline $0.2-0.4$ & 1.62 & 0.05 & 0.06 & $1.8 \pm 0.8$ & $0.4 \pm 0.3$ & $0.03 \pm 0.01$ & $7.3 \pm 0.3$ & b.d. \\
\hline $0.4-0.6$ & 1.80 & 0.16 & 0.21 & $5.4 \pm 4.9$ & $2.5 \pm 1.5$ & $0.11 \pm 0.05$ & $8.8 \pm 0.6$ & 0.90 \\
\hline $0.6-0.8$ & 1.54 & 0.18 & 0.29 & $10.1 \pm 6.8$ & $6.8 \pm 3.9$ & $0.19 \pm 0.08$ & $9.4 \pm 0.3$ & \\
\hline $0.8-1.0$ & 1.73 & 0.25 & 0.33 & $10.1 \pm 6.8$ & $6.8 \pm 3.9$ & $0.19 \pm 0.08$ & $9.4 \pm 0.3$ & \\
\hline \multicolumn{9}{|c|}{ Mid-slope } \\
\hline $0-0.1$ & 1.70 & 0.03 & 0.10 & $1.3 \pm 0.3$ & $0.5 \pm 0.09$ & $0.04 \pm 0.008$ & $6.7 \pm 0.4$ & 0.64 \\
\hline $0.1-0.2$ & 1.81 & 0.09 & 0.20 & $2.7 \pm 2.9$ & $0.6 \pm 0.4$ & $0.04 \pm 0.02$ & $7.0 \pm 0.6$ & 0.21 \\
\hline $0.2-0.4$ & 1.82 & 0.17 & 0.30 & $3.3 \pm 2.0$ & $1.8 \pm 0.8$ & $0.12 \pm 0.04$ & $8.6 \pm 0.3$ & 0.07 \\
\hline $0.4-0.6$ & 1.63 & 0.15 & 0.34 & $6.7 \pm 5.7$ & $5.9 \pm 4.6$ & $0.19 \pm 0.08$ & $9.1 \pm 0.4$ & b.d. \\
\hline $0.6-0.8$ & 1.71 & 0.24 & 0.34 & $20.6 \pm 6.7$ & $14.0 \pm 4.8$ & $0.42 \pm 0.09$ & $9.6 \pm 0.2$ & \\
\hline $0.8-1.0$ & 1.81 & 0.29 & 0.34 & $20.6 \pm 6.7$ & $14.0 \pm 4.8$ & $0.42 \pm 0.09$ & $9.6 \pm 0.2$ & \\
\hline \multicolumn{9}{|c|}{ Swale } \\
\hline $0-0.1$ & 1.38 & 0.04 & 0.20 & $6.0 \pm 7.0$ & $1.7 \pm 1.9$ & $0.05 \pm 0.008$ & $6.4 \pm 0.2$ & 1.71 \\
\hline $0.1-0.2$ & 1.47 & 0.14 & 0.20 & $9.6 \pm 6.6$ & $4.7 \pm 6.0$ & $0.16 \pm 0.03$ & $8.1 \pm 0.2$ & 0.78 \\
\hline $0.2-0.4$ & 1.46 & 0.18 & 0.34 & $17.6 \pm 9.0$ & $11.1 \pm 8.0$ & $0.34 \pm 0.09$ & $9.4 \pm 0.2$ & 0.39 \\
\hline $0.4-0.6$ & 1.65 & 0.21 & 0.38 & $31.3 \pm 11.7$ & $18.2 \pm 6.7$ & $0.59 \pm 0.2$ & $9.6 \pm 0.1$ & 0.08 \\
\hline $0.6-0.8$ & 1.70 & 0.24 & 0.39 & $30.2 \pm 19.8$ & $9.2 \pm 6.0$ & $0.98 \pm 0.5$ & $8.4 \pm 0.8$ & \\
\hline $0.8-1.0$ & 1.70 & 0.26 & 0.41 & $30.2 \pm 19.8$ & $9.2 \pm 6.0$ & $0.98 \pm 0.5$ & $8.4 \pm 0.8$ & \\
\hline
\end{tabular}

Table 3. Break-crop treatments imposed in 2009-12

DP, Dual-purpose for hay and grain

\begin{tabular}{|c|c|c|c|c|}
\hline Treatment & 15 May 2009 & 27 May 2010 & 24 May 2011 & 30 May 2012 \\
\hline 1 & Legume (peas) & Correll wheat & Mace wheat & Kord CL Plus ${ }^{\circledR}$ whea \\
\hline 2 & Cereal rye & Correll wheat & Mace wheat & Kord CL Plus ${ }^{\circledR}$ whea \\
\hline 3 & DP cereal rye & Correll wheat & Mace wheat & Kord CL Plus ${ }^{\circledR}$ whea \\
\hline 4 & Volunteer pasture & Correll wheat & Mace wheat & Kord CL Plus ${ }^{\circledR}$ whea \\
\hline 5 & Correll wheat (control) & Correll wheat & Mace wheat & Kord CL Plus ${ }^{\circledR}$ whea \\
\hline 6 & Correll wheat & Brassica (canola) & Mace wheat & Kord CL Plus ${ }^{\circledR}$ whea \\
\hline 7 & Correll wheat & Cereal rye & Mace wheat & Kord CL Plus ${ }^{\circledR}$ whea \\
\hline 8 & Correll wheat & DP cereal rye & Mace wheat & Kord CL Plus ${ }^{\circledR}$ whea \\
\hline 9 & Correll wheat & Volunteer pasture & Mace wheat & Kord CL Plus ${ }^{\circledR}$ whea \\
\hline 10 & Correll wheat & Legume (lupins) & Mace wheat & Kord CL Plus ${ }^{\circledR}$ whea \\
\hline
\end{tabular}


points (50-mm wings) and press-wheels spaced $0.23 \mathrm{~m}$ apart, with each plot $1.6 \mathrm{~m}$ wide and $40 \mathrm{~m}$ long. The mid-slope and crest plots were treated as a single plot in 2009. After harvest in 2009 , the plots were split in half $(20 \mathrm{~m}$ each $)$ because differences in soil type and productive potential became apparent. Treatments 1-4 were sown to breaks in 2009 and followed by wheat crops sown in the 2010-12 growing seasons. Treatment 5 was sown to wheat in every growing season. Treatments 6-10 were sown to breaks in 2010, with wheat sown in 2009 and 2011-12. The brassica break was canola (Brassica napus cv. Hyola) in 2010. Field peas (Pisum sativum cv, Kaspa) were sown as the grain legume break in 2009 but owing to concerns about low biomass resulting in increased potential for soil erosion, the grain legume break was lupins (Lupinus angustifolius cv. Mandelup) in 2010. The experiments were laid out in a completely randomised block design with four replicates, and the design was applied four times to the dune, crest, mid-slope and swale soil types.

\section{Crop management}

All crop types were managed according to district practice for that crop; hence, there were some differences in the inputs of seed and $\mathrm{N}$ for different crops but all wheat crops received the same level of sowing inputs to allow comparison of break effects (Table 4). The wheat cultivar selected in each growing season was rotated to minimise pressure on weed and disease management. Wheat cv. Correll was grown in 2009 and 2010 and rotated to cv. Mace in 2011 after yellow leaf spot build-up in 2010, and rotated from cv. Mace to cv. Kord CL Plus ${ }^{\circledR}$ in 2012 to enable weed pressure and stripe rust to remain at low levels. The volunteer pasture was not sown or fertilised in May as per the other treatments. The pasture composition changed with soil type, with a composition of $\sim 85 \%$ medic (Medicago spp.) on the dune, $50 \%$ on the mid-slope and $40 \%$ on the swale. The remainder of the pasture composition was annual winter grasses with a dominance of annual ryegrass (Lolium rigidum Gaudin.) in the swale and brome grass (Bromus diandrus) in the dune,

Table 4. Sowing inputs applied to each crop type in 2009-12 DP, Dual-purpose for hay and grain. All phosphorus (P) supplied as diammonium phosphate (DAP); nitrogen (N) supplied as urea $\left(16 \mathrm{~kg} \mathrm{Nha}^{-1}\right)$ and DAP $\left(9 \mathrm{kgNha}^{-1}\right)$; sulfur (S) supplied as gypsum (Meningie Gypsum, $\left.\sim 17 \mathrm{~kg} \mathrm{Sha}^{-1}\right)$ and DAP $\left(1 \mathrm{~kg} \mathrm{Sha}^{-1}\right)$

\begin{tabular}{|c|c|c|c|}
\hline Treatments & Crop and cultivar & $\begin{array}{c}\text { Seed } \\
\left(\mathrm{kg} \mathrm{ha}^{-1}\right)\end{array}$ & $\begin{array}{c}\text { Nutrients } \\
\left(\mathrm{N}: \mathrm{P}: \mathrm{S} \mathrm{kg} \mathrm{ha}^{-1}\right)\end{array}$ \\
\hline Legume & $\begin{array}{l}\text { Field peas (Pisum sativum) } \\
\text { cv. Kaspa (2009) } \\
\text { Lupin (Lupinus angustifolius) } \\
\text { cv. Mandelup (2010) }\end{array}$ & $\begin{array}{r}100 \\
90\end{array}$ & $\begin{array}{l}9: 10: 18 \\
9: 10: 18\end{array}$ \\
\hline Brassica & $\begin{array}{l}\text { Canola (Brassica napus) } \\
\text { cv. Hyola } 50 \text { (2010) }\end{array}$ & 5 & $25: 10: 18$ \\
\hline Cereal rye & $\begin{array}{l}\text { Cereal rye (Secale cereale) } \\
\text { cv. Bevy }\end{array}$ & 80 & $25: 10: 18$ \\
\hline DP cereal rye & Cereal rye cv. Bevy & 80 & $25: 10: 18$ \\
\hline $\begin{array}{l}\text { Volunteer } \\
\text { pasture }\end{array}$ & Volunteer pasture & 0 & $0: 0: 17$ \\
\hline Wheat & $\begin{array}{l}\text { Wheat (Triticum aestivum) } \\
\text { cv. Correll (2009 and 2010), } \\
\text { Mace (2011), Kord CL } \\
\left.\text { Plus }{ }^{\circledR}(2012)\right)\end{array}$ & 70 & $25: 10: 18$ \\
\hline
\end{tabular}

and broadleaf weeds including capeweed (Arctotheca calendula) and wild turnip (Rapistrum rugosum) predominantly in the dune. The volunteer pasture was spray-topped with Spraytop $200^{\circledR}$ (Farmoz, St Leonards, NSW) applied at $400 \mathrm{~mL} \mathrm{ha}^{-1}$ on 9 October 2009 and 7 October 2010. All plots were managed with low weed pressure over the summer fallow with up to four applications of herbicide during this period.

All plots received trace element fertilisers to ensure that nutrients other than $\mathrm{N}$ were not limiting. Crop plots were maintained in-season with the aim of minimising weed impact. This was successfully achieved through use of a wide range of herbicides applied equally across all soil types.

\section{In-season measurements}

Segmented soil cores to $1 \mathrm{~m}$ depth were taken in each plot before sowing in each year of the experiment. The cores were divided into depths of $0-0.1,0.1-0.2,0.2-0.4,0.4-0.6$ and $0.8-1.0 \mathrm{~m}$. The subsamples were analysed for pre-sowing gravimetric water content in order to calculate PAW. The pre-sowing samples were immediately dried at $40^{\circ} \mathrm{C}$ for 10 days. Samples were bulked at increments of $0-0.1,0.1-0.6$ and $0.6-1.0 \mathrm{~m}$ and then ground (mortar and pestle) and sieved $(<2 \mathrm{~mm})$ for nitrate-N and ammonium-N analysis. Soil nitrate- $\mathrm{N}$ and ammonium-N were analysed according to Method $7 \mathrm{C} 2 \mathrm{~b}$ of Rayment and Lyons (2011).

In each year, surface soil samples $(0-0.1 \mathrm{~m})$ were collected 1-2 days before sowing and analysed for the $\mathrm{N}$ supply potential (NSP). Field-moist soil samples were sieved through a 2-mm sieve to remove undecomposed plant residues and stones and incubated for $48 \mathrm{~h}$ to stabilise before analysis. The amount of microbial biomass $\mathrm{N}$ (MBN) was determined by measuring colourimetric ninhydrin-reactive $\mathrm{N}$ levels in $0.5 \mathrm{M} \mathrm{K} \mathrm{K}_{2} \mathrm{SO}_{4}$ extractions before and after a 10-day chloroform fumigation; the MBN was derived from $\mathrm{k}_{\mathrm{EN}}$ value of 3.8 (Sparling et al. 1993). To quantify potentially mineralisable N (PMN), $100 \mathrm{~g}$ of soil for each sample was incubated (aerobic) for 21 days at $25^{\circ} \mathrm{C}$ and PMN was calculated from the difference in mineral $\mathrm{N}$ (ammonium and nitrate) extracted by $2 \mathrm{M} \mathrm{KCl}$ at the start and after 21 days (Rayment and Lyons 2011). To calculate NSP, we assumed that $50 \%$ of MBN would be released for plant uptake from microbial turnover and predation by fauna and all of the PMN.

In each year, at 7 weeks after sowing, 20 plants were collected from each plot for selected treatments; roots were washed and rated for disease on a $0-5$ scale: 0 , no disease; 5 , all primary roots infected and severely truncated (McDonald and Rovira 1985). In addition, the number of total and infected seminal and crown roots and the length of the internode were also recorded.

Winter biomass was measured at 10 weeks after sowing in 2009 and 8 weeks after sowing in 2010 by cutting and removing all aboveground plant material from four replicates of $0.5 \mathrm{~m}$ by $0.5 \mathrm{~m}$ quadrats within each plot.

Plots were machine-harvested at maturity to measure grain yield. Dried wheat-grain samples $(\sim 12 \% \mathrm{w} / \mathrm{w}$ moisture $)$ were analysed for protein using a FOSS ${ }^{\circledR}$ NIR analyser. The wheat grain $\mathrm{N}$ yield $\left(\mathrm{kg} \mathrm{ha}^{-1}\right)$ was calculated as: wheat grain yield $\left(\mathrm{kg} \mathrm{ha}^{-1}\right) \times$ grain $\mathrm{N}\left(\mathrm{kg} \mathrm{kg}^{-1}\right)$. 
Water-use efficiency (WUE, $\mathrm{kg} \mathrm{ha}^{-1} \mathrm{~mm}^{-1}$ ) was calculated as: grain yield $\left(\mathrm{kgha}^{-1}\right) \div$ water use $(\mathrm{mm})$, where water use $=$ growing-season rainfall $(\mathrm{mm})+$ PAW at sowing $(\mathrm{mm})$. The water-use value did not include subtraction of the amount of soil water at harvest.

\section{Agricultural Production Systems Simulator (APSIM)-derived yield potential}

Water-limited wheat yield potential (with no $\mathrm{N}$ limitation) and yield potential at sowing $\mathrm{N}$ and water levels measured in wheat following a 2010 lupin crop were modelled for each of the four soil types in the 2011 and 2012 growing seasons using APSIM version 7.3 (Keating et al. 2003). These modelled yields were compared with the yield achieved with wheat grown following a 2010 lupin crop (generally the best performing break) and continuous wheat. The APSIM modules utilised in the analysis were Wheat (wheat crop growth and development), SoilWat (soil water balance), SoilN (soil N dynamics), SurfaceOM (surface residue dynamics) and Manager (management rules), as described by Hunt and Kirkegaard (2011). The use of APSIM for the simulation of wheat response to soil water and $\mathrm{N}$ has been widely tested and validated in Australian cropping systems (Asseng et al. 1998a; Probert et al. 1998; Carberry et al. 2002; Hayman et al. 2010; Sadras and Rodriguez 2010; Hunt and Kirkegaard 2011; Verburg et al. 2012). The fit of modelled $v$. actual data for wheat yield at Karoonda and on the same soil types $\left(R^{2}=0.84, \quad \mathrm{RMSE}=0.3 \mathrm{tha}^{-1}\right)$ has been previously demonstrated in Monjardino et al. (2013). Weather data were obtained from an onsite weather station, and missing data points were patched with data from the SILO Patched Point Dataset for the nearby Australian Bureau of Meteorology at Karoonda (station 025006).

The APSIM-Manager rules used were based on a sowing on the same day that the field experiment was sown in 2011 and 2012. Nitrogen was applied as urea at $25 \mathrm{~kg} \mathrm{Nha}^{-1}$. Soil inputs of crop lower limit, drained upper limit, bulk density, organic $\mathrm{C}$ and EC were all derived from the properties measured in Table 2. Soil water and $\mathrm{N}$ were reset to soil test values on the date that the soil test was taken. The surface organic matter was reset to $1.5 \mathrm{tha}^{-1}$ with a $\mathrm{C}: \mathrm{N}$ ratio of 80 at the same time.

\section{Statistical analyses}

All data was analysed with GENSTAT 13th Edn (VSN International: Hemel Hempstead, UK) using a restricted maximum likelihood (REML) multiple experiments analysis of the design: fixed model $=$ treatment. soil + treatment + soil, random model $=$ soil . replicate, and experiments $=$ soil. Each year was analysed independently because the treatments were not the same every year. Assumptions of normality of data distribution and additivity of treatment and replicate effects were tested for each analysis. For significant effects, least significant difference (1.s.d.) was used for comparison between treatment means.

\section{Results}

Yields

\section{Yield by crop type, 2009-12}

The best yielding season for all crop types during the trial was 2010, with yields on the swale exceeding the other soil types. The most productive soil type in the drier season of 2009 was the sandy topsoils of the dune and mid-slope. Using a multisite REML analysis, the level of variance was found to differ between soil types, so the relative yield differences between crop types differed on each soil. Winter biomass data indicated relatively small differences between soil types within a crop type except for canola, which had substantially lower biomass on the sandy topsoils of the dune and crest in 2010 (Table 5). Cereal rye (Secale cereale cv. Bevy) produced substantial amounts of biomass compared with the other crop types, whereas the grain legumes tended to produce lower levels of biomass than the cereals (Table 5). In 2009, rye and wheat produced similar levels of grain on the dune and mid-slope, while on the swale, rye and field peas produced similar amounts of grain, both less than wheat (Table 5). In 2010, wheat was the best yielding crop on the mid-slope and swale, while lupins yielded the best on the dune and crest. Canola was the lowest yielding crop on all soils (Table 5).

Harvest residue samples from each crop type at this site were analysed in duplicate for $\mathrm{C}: \mathrm{N}$ ratio in 2010, with resultant ratios of 154 for wheat, 161 for rye, 130 for canola and 81 for lupin (Noack et al. 2012).

\section{Wheat yields following breaks, 2010-12}

A multi-site REML analysis showed that the level of variance did not differ between soil types, suggesting that wheat yield differences caused by crop sequence did not differ between soil types. In 2010, the predicted mean indicated that the best break for increasing wheat yield over continuous wheat was field peas, which gave a benefit equal to pasture and better than rye (Table 6). In 2011, the ranking of first-year break effects was similar to 2010, with legume-based breaks (lupins and pasture) having the greatest effect. The break effect of canola was similar to pasture but not as great as lupins, whereas rye did not have a significant break effect. Field peas and pasture both had significant second-year break effects in 2011. In 2012, the second wheat crop after lupins yielded significantly more than continuous wheat or wheat grown after cereal rye, but was similar in yield to wheat grown after other break treatments (Table 6).

Analysis of the regression between yields of continuous wheat and wheat following break (Fig. 1) suggested that the most appropriate model was three parallel lines with a common slope of 0.97 continuous wheat yield $(P<0.001$, $\left.R^{2}=0.93\right)$. The slope was not significantly different from 1 (standard error 0.03); therefore, the break effect was equivalent to the intercept, which was $0.70 \mathrm{t}$ (s.e. $0.11 \mathrm{t})$ in the first year following the break (Fig. 1a), $0.35 \mathrm{t}($ s.e. $0.09 \mathrm{t}$ ) in the second year (Fig. $1 b$ ) and $0.15 \mathrm{t}$ (s.e. $0.07 \mathrm{t}$ ) in the third year (all $P<0.05$ ). Although all three lines show a significant difference between yields of continuous wheat and wheat following break, in agronomic terms, the thirdyear break effect was minor and the line for this regression is not presented.

\section{Nitrogen yields in grain following breaks, 2010-12}

The wheat grain $\mathrm{N}$ yield was calculated to integrate the effect of treatment on grain protein and yield. The $\mathrm{N}$ yield was 
Table 5. Winter biomass (dry weight, $\mathrm{t} \mathrm{ha}^{-1}$ ) at 10 weeks after sowing in 2009 and 8 weeks after sowing in 2010 , and grain yields $\left(\mathrm{t} \mathrm{ha}{ }^{-1}\right.$ ) in 2009 and 2010 of the different crop types on each soil type

DPR, Dual-purpose hay and grain rye; CW, continuous wheat. Note that the mid-slope and crest plots were treated as a single plot in 2009; after harvest in 2009, the plots were split in half as differences when soil type and productive potential became apparent. Medic biomass calculated from estimated composition of $85 \%$ medic in dune, $50 \%$ medic in mid-slope and $40 \%$ medic in swale Within a season, grain yields for soil $\times$ crop type combinations followed by the same letter are not significantly different at $P=0.05$

\begin{tabular}{|c|c|c|c|c|c|c|c|c|}
\hline & \multicolumn{4}{|c|}{ Winter biomass } & \multicolumn{4}{|c|}{ Grain yield } \\
\hline & Dune & Crest & Mid-slope & Swale & Dune & Crest & Mid-slope & Swale \\
\hline \multicolumn{9}{|c|}{2009} \\
\hline Field peas & $0.44 \mathrm{e}$ & \multicolumn{2}{|c|}{$0.48 \mathrm{e}$} & $0.58 \mathrm{de}$ & $0.59 \mathrm{de}$ & \multicolumn{2}{|c|}{$0.69 \mathrm{de}$} & $0.69 \mathrm{de}$ \\
\hline $\mathrm{CW}$ & $0.74 \mathrm{~cd}$ & \multicolumn{2}{|c|}{$0.67 \mathrm{cde}$} & $0.90 \mathrm{c}$ & $1.77 \mathrm{ab}$ & \multicolumn{2}{|c|}{$1.94 \mathrm{a}$} & $1.40 \mathrm{bc}$ \\
\hline Pasture & $0.62 \mathrm{de}$ & & & $2.28 \mathrm{a}$ & & & & \\
\hline (Medic) & & & & 2010 & & & & \\
\hline Canola & $0.75 \mathrm{ghi}$ & 0.88 fgh & $1.46 \mathrm{c}$ & $1.44 \mathrm{c}$ & $1.87 \mathrm{i}$ & $1.14 \mathrm{j}$ & $1.35 \mathrm{j}$ & 2.04hi \\
\hline Rye & $1.17 \mathrm{cdef}$ & $1.01 \mathrm{defg}$ & $1.33 \mathrm{cde}$ & $1.36 \mathrm{~cd}$ & $3.10 \mathrm{de}$ & $2.88 \mathrm{ef}$ & $3.43 \mathrm{~cd}$ & $3.36 \mathrm{cde}$ \\
\hline DPR & & & & & $2.39 \mathrm{gh}$ & $1.92 \mathrm{hi}$ & $2.39 \mathrm{gh}$ & 2.32ghi \\
\hline Lupins & $0.48 \mathrm{ij}$ & $0.42 \mathrm{ij}$ & $0.60 \mathrm{hij}$ & $0.40 \mathrm{ij}$ & $3.80 \mathrm{bc}$ & $4.00 \mathrm{~b}$ & $3.27 \mathrm{de}$ & $2.55 \mathrm{fg}$ \\
\hline
\end{tabular}

strongly affected by soil type, with the swale having the highest $\mathrm{N}$ yield in all seasons, followed by the dune and mid-slope with equivalent $\mathrm{N}$ yield, and the crest having the lowest $\mathrm{N}$ yield in all seasons (Table 7). The break effects on $\mathrm{N}$ yield were consistent with those for grain yield. In 2010, plots with legume breaks in 2009 (field peas and pasture) had in the highest $\mathrm{N}$ yield. In 2011, plots with breaks in 2010 (lupins, pasture and canola) had the highest wheat $\mathrm{N}$ yield. In 2012, there was an effect of 2010 legume breaks (lupins and pasture) (Table 7).

\section{Soil mineral N}

Most of the differences in soil mineral $\mathrm{N}$ were between soil types, with the heavy swale and mid-bottom having higher levels of soil mineral $\mathrm{N}$ than the crest and dune (Table 8). In 2010, the 2009 legume breaks (field peas and pasture) resulted in higher levels of soil mineral $\mathrm{N}$ than the other treatments, suggesting that mineral $\mathrm{N}$ was a likely component of the break effect in these treatments, which had the highest wheat yields (Table 8). Soil mineral N levels were trending upwards with time for all soil types, suggesting that sowing fertiliser-N inputs of $25 \mathrm{~kg} \mathrm{ha}^{-1}$ combined with soil available resources were greater than the level of $\mathrm{N}$ removal.

In 2010, NSP measurements were made only in continuous wheat plots. The NSP ranged from 22 to $32 \mathrm{~kg} \mathrm{~N} \mathrm{ha}^{-1}$ season $^{-1}$ (Table 9), with levels significantly higher in the swale than in the sandy mid-slope and dune. In 2011, NSP was significantly higher $(>60 \%)$ than that observed in 2010 across all the treatments and soil zones. During 2011, the NSP was higher following legumes and canola than after cereal rye or in continuous wheat, except on the dune. In the dune, canola resulted in an increase in NSP compared with continuous wheat. In 2012, a pasture caused the greatest second-year carryover benefit in NSP (40-53\% over continuous wheat). In general, the canola effect decreased in the second year (2012) in both the dune and swale soils.

\section{Soil-borne disease}

There was a significant soil type effect on the level of disease in all 3 years and it varied between seasons (Table 10). In general, incidence of rhizoctonia disease was highest in the 2010 growing season, followed by 2012 , with the lowest levels in 2011 (Table 10) after record summer rains in the fallow period before the 2011 crop. During 2011 and 2012, disease incidence was higher in the crop on the swale, whereas in 2010, disease incidence was significantly lower on the swale than on the midslope. These trends were seen for both the overall root rating score and the crown root infection. The internode length was generally shorter on the swale than the mid-slope and dune experiments, whereas the total number of crown roots at the time of sampling (7 weeks after sowing) was generally higher on the swale.

The effect of crop type on rhizoctonia disease incidence in the following wheat crop was variable and influenced by crop season (Table 10). During 2011 when the rhizoctonia disease incidence was generally low, the effect of the 2010 break (firstyear effect) was not significant.

In 2012, the second-year effect of all 2010 breaks except lupins was significant in lowering rhizoctonia root rating score compared with continuous on the swale; however, there was no significant effect on the dune crop (Fig. 2). 
Table 6. Wheat yields $\left(\mathrm{tha}^{-1}\right)$ in 2010-12 following breaks in 2009 and 2010, with the crop sequence for 2009-12 shown on the left and the crop for which yield is presented shown in bold

W, Wheat; FP, field pea; R, rye; DPR, dual purpose hay and grain rye; Pa, pasture; C, canola; L, lupin. Within a season, predicted treatment means, or soil means, followed by the same letter are not significantly different at $P=0.05$. Interaction between soil and treatment was not significant

\begin{tabular}{|c|c|c|c|c|c|}
\hline Crop sequence & Dune & Crest & Mid-slope & Swale & $\begin{array}{l}\text { Treatment } \\
\text { mean }\end{array}$ \\
\hline \multicolumn{6}{|c|}{2010} \\
\hline W-W-W-W & 2.99 & 2.24 & 4.03 & 5.17 & $3.61 \mathrm{~d}$ \\
\hline \multicolumn{6}{|c|}{ First-year effects } \\
\hline $\mathrm{FP}-\mathbf{W}-\mathrm{W}-\mathrm{W}$ & 3.95 & 3.10 & 5.00 & 6.11 & $4.54 \mathrm{a}$ \\
\hline $\mathrm{R}-\mathbf{W}-\mathrm{W}-\mathrm{W}$ & 3.27 & 2.36 & 4.39 & 5.87 & $3.97 \mathrm{c}$ \\
\hline DPR-W-W-W & 3.19 & 2.94 & 4.52 & 6.08 & $4.18 \mathrm{bc}$ \\
\hline $\mathrm{Pa}-\mathbf{W}-\mathrm{W}-\mathrm{W}$ & 4.11 & 3.10 & 4.66 & 5.89 & $4.44 \mathrm{ab}$ \\
\hline Soil mean & $3.52 \mathrm{c}$ & $2.75 d$ & $4.52 \mathrm{~b}$ & $5.83 a$ & $\begin{array}{c}\text { Treat. 1.s.d. } 0.33 \\
\text { Soil 1.s.d. } 0.31\end{array}$ \\
\hline \multicolumn{6}{|c|}{2011} \\
\hline W-W-W-W & 3.60 & 2.17 & 3.48 & 3.75 & $3.25 \mathrm{e}$ \\
\hline \multicolumn{6}{|c|}{ First-year effects } \\
\hline $\mathrm{W}-\mathrm{C}-\mathbf{W}-\mathrm{W}$ & 3.91 & 2.45 & 3.78 & 4.46 & $3.65 b c$ \\
\hline $\mathrm{W}-\mathrm{R}-\mathrm{W}-\mathrm{W}$ & 4.24 & 2.66 & 3.39 & 3.72 & $3.51 \mathrm{~cd}$ \\
\hline W-DPR-W-W & 3.86 & 2.47 & 3.71 & 3.71 & $3.44 \mathrm{cde}$ \\
\hline $\mathrm{W}-\mathrm{Pa}-\mathbf{W}-\mathrm{W}$ & 3.77 & 3.16 & 4.20 & 4.27 & $3.85 \mathrm{ab}$ \\
\hline W-L-W-W & 4.30 & 3.01 & 4.08 & 4.67 & $4.02 \mathrm{a}$ \\
\hline \multicolumn{6}{|c|}{ Second-year effects } \\
\hline FP-W-W-W & 3.68 & 2.41 & 3.78 & 4.38 & $3.56 \mathrm{~cd}$ \\
\hline $\mathrm{R}-\mathrm{W}-\mathbf{W}-\mathrm{W}$ & 3.65 & 2.43 & 3.65 & 3.89 & $3.41 \mathrm{cde}$ \\
\hline DPR-W-W-W & 3.32 & 2.27 & 3.38 & 4.40 & $3.34 \mathrm{de}$ \\
\hline $\mathrm{Pa}-\mathrm{W}-\mathbf{W}-\mathrm{W}$ & 3.71 & 2.73 & 3.77 & 4.22 & $3.61 \mathrm{bc}$ \\
\hline Soil mean & $3.81 \mathrm{~b}$ & $2.58 \mathrm{c}$ & $3.71 \mathrm{~b}$ & $4.15 \mathrm{a}$ & $\begin{array}{l}\text { Treat. 1.s.d. } 0.26 \\
\text { Soil l.s.d. } 0.22\end{array}$ \\
\hline \multicolumn{6}{|c|}{2012} \\
\hline W-W-W-W & 2.09 & 1.30 & 2.56 & 3.43 & $2.36 \mathrm{bc}$ \\
\hline \multicolumn{6}{|c|}{ Second-year effects } \\
\hline $\mathrm{W}-\mathrm{C}-\mathrm{W}-\mathbf{W}$ & 2.53 & 1.61 & 2.70 & 3.79 & $2.64 \mathrm{ab}$ \\
\hline $\mathrm{W}-\mathrm{R}-\mathrm{W}-\mathbf{W}$ & 2.15 & 1.56 & 2.40 & 3.49 & $2.48 \mathrm{abc}$ \\
\hline W-DPR-W-W & 2.02 & 1.48 & 2.20 & 3.49 & $2.33 c$ \\
\hline W-Pa-W-W & 2.47 & 1.89 & 3.01 & 3.56 & $2.62 \mathrm{abc}$ \\
\hline W-L-W-W & 2.41 & 1.88 & 3.04 & 3.54 & $2.73 \mathrm{a}$ \\
\hline \multicolumn{6}{|c|}{ Third-year effects } \\
\hline FP-W-W-W & 2.34 & 1.51 & 2.83 & 3.50 & $2.54 a b c$ \\
\hline $\mathrm{R}-\mathrm{W}-\mathrm{W}-\mathbf{W}$ & 2.15 & 1.56 & 2.40 & 3.49 & $2.48 \mathrm{abc}$ \\
\hline DPR-W-W-W & 2.02 & 1.48 & 2.20 & 3.49 & $2.33 \mathrm{c}$ \\
\hline $\mathrm{Pa}-\mathrm{W}-\mathrm{W}-\mathbf{W}$ & 2.47 & 1.89 & 3.01 & 3.56 & $2.62 \mathrm{abc}$ \\
\hline Soil mean & $2.28 \mathrm{c}$ & $1.58 \mathrm{~d}$ & $2.67 \mathrm{~b}$ & $3.57 \mathrm{a}$ & $\begin{array}{l}\text { Treat. 1.s.d. } 0.30 \\
\text { Soil 1.s.d. } 0.14\end{array}$ \\
\hline
\end{tabular}

\section{Plant-available water and water-use efficiency}

Pre-sowing PAW was analysed in the first and second wheat crop following a break. The results showed a strong seasonal effect with highest values in 2011 and lowest in 2009 (Table 11). PAW showed high variance in all seasons, with some minor treatment effects observed in 2010 where a pasture break on the swale consumed more PAW than continuous wheat (Table 11). The summer of 2010-11 was very wet, and as a result, the only observed differences in

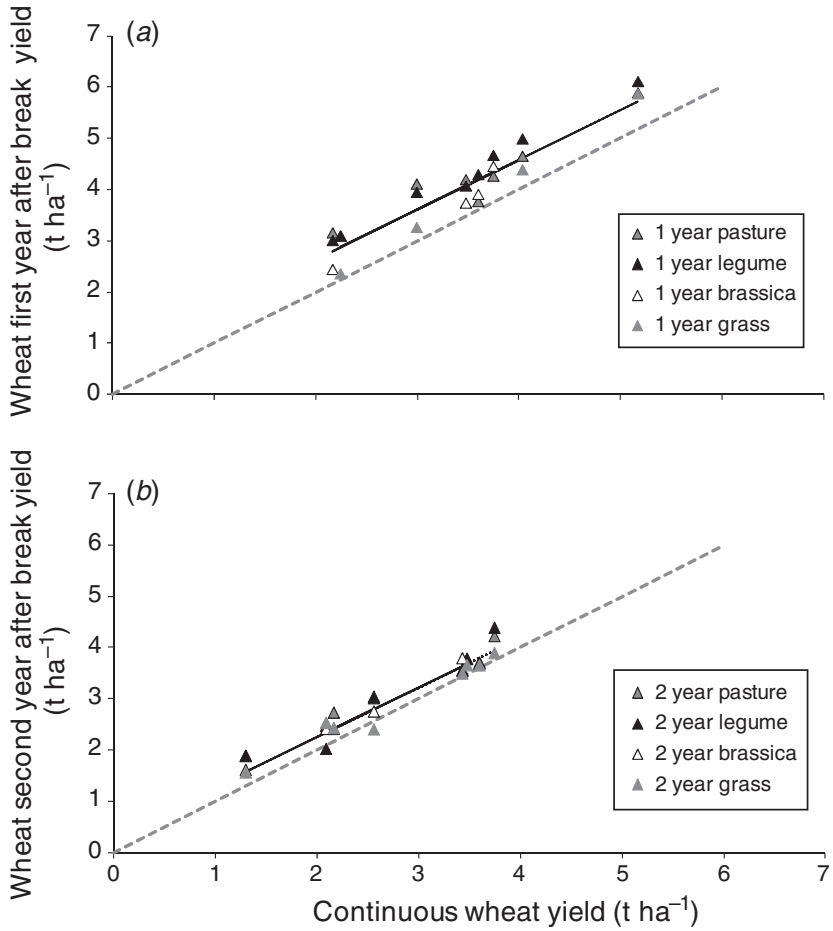

Fig. 1. Regression between yields of wheat following break and continuous wheat $(\mathrm{CW})$. Equations are: for $(a)$ wheat yield first year after a break $=0.70+0.97 \mathrm{CW}$ yield; for $(b)$ wheat yield second year after a break $=0.31+0.97 \mathrm{CW}$ yield $\left(P<0.001, R^{2}=0.93\right)$. The dashed line represents the $1: 1$ relationship.

PAW were between soils with very high levels of PAW in the dune and crest at sowing (Table 11). Two years after a break, in 2012, there were some small treatment effects on subsequent PAW, with a 2010 pasture break in the swale having more sowing PAW than a 2010 rye break.

The WUE was used to integrate the effect of treatment on yield and crop water supply. WUE was affected by soil type and by season conditions, with 2010 showing highest WUE for the dune followed by the swale then the mid-slope and crest, whereas in 2011 and 2012, the heavier swale had the highest WUE followed by the mid-slope then dune and crest (Table 11). Treatment effects on WUE were strongly related to significant yield effects, with 2009 legume breaks (field peas and pasture) resulting in the highest 2010 wheat WUE, 2010 legume breaks (lupins and pasture) resulting in the highest 2011 wheat WUE, with no carryover second- or third-year effects measured in 2012 (Table 11).

\section{The role of the break crop in filling the yield gap}

To examine whether a break crop in a sequence can close the gap between attained yield and water-limited yield potential, we used a modelling analysis to estimate the yield potential in 2011 and 2012 when soil $\mathrm{N}$ supply was unlimited, and the yield potential arising from the soil water and $\mathrm{N}$ resources measured after inclusion of a break in the sequence. The analysis demonstrated that the 2011 yield of wheat following a 2010 lupin crop was equivalent to the modelled water- and 
Table 7. Nitrogen yield from grain $\left(\mathrm{kg} \mathrm{ha}^{-1}\right)$ in 2010-12 following breaks in 2009 and 2010 with the crop sequence for 2009-12 shown on the left, and the crop for which protein is presented shown in bold $\mathrm{W}$, Wheat; FP, field pea; R, rye; DPR, dual purpose hay and grain rye; Pa, pasture; C, canola; L, lupin. Within a season, predicted treatment means, or soil means, followed by the same letter are not significantly different at $P=0.05$

\begin{tabular}{|c|c|c|c|c|c|}
\hline Crop sequence & Dune & Crest & Mid-slope & Swale & Treatment mean \\
\hline \multicolumn{6}{|c|}{2010} \\
\hline $\mathrm{W}-\mathbf{W}-\mathrm{W}-\mathrm{W}$ & 59 & 40 & 66 & 94 & $65 b$ \\
\hline \multicolumn{6}{|c|}{ First-year effects } \\
\hline FP-W-W-W & 69 & 53 & 81 & 120 & $81 \mathrm{a}$ \\
\hline $\mathrm{R}-\mathbf{W}-\mathrm{W}-\mathrm{W}$ & 57 & 40 & 69 & 113 & $70 \mathrm{~b}$ \\
\hline DPR-W-W-W & 38 & 48 & 70 & 110 & $66 \mathrm{~b}$ \\
\hline $\mathrm{Pa}-\mathbf{W}-\mathrm{W}-\mathrm{W}$ & 74 & 54 & 79 & 108 & $79 a$ \\
\hline Soil mean & $59 \mathrm{c}$ & $47 d$ & $73 b$ & $109 a$ & $\begin{array}{c}\text { Treat. 1.s.d. } 8 \\
\text { Soil 1.s.d. } 8\end{array}$ \\
\hline \multicolumn{6}{|c|}{2011} \\
\hline $\mathrm{W}-\mathrm{W}-\mathbf{W}-\mathrm{W}$ & 60 & 38 & 58 & 78 & $58 \mathrm{~d}$ \\
\hline \multicolumn{6}{|c|}{ First-year effects } \\
\hline $\mathrm{W}-\mathrm{C}-\mathbf{W}-\mathrm{W}$ & 88 & 42 & 64 & 88 & $65 \mathrm{bc}$ \\
\hline W-R-W-W & 72 & 44 & 56 & 72 & $60 \mathrm{~cd}$ \\
\hline W-DPR-W-W & 74 & 41 & 64 & 74 & $62 \mathrm{~cd}$ \\
\hline W-Pa-W-W & 88 & 53 & 72 & 88 & $70 \mathrm{ab}$ \\
\hline W-L-W-W & 103 & 52 & 69 & 103 & $75 \mathrm{a}$ \\
\hline \multicolumn{6}{|c|}{ Second-year effects } \\
\hline FP-W-W-W & 87 & 39 & 63 & 87 & $63 \mathrm{~cd}$ \\
\hline R-W-W-W & 80 & 42 & 59 & 80 & $61 \mathrm{~cd}$ \\
\hline DPR-W-W-W & 91 & 37 & 56 & 91 & $61 \mathrm{~cd}$ \\
\hline $\mathrm{Pa}-\mathrm{W}-\mathbf{W}-\mathrm{W}$ & 87 & 46 & 61 & 87 & $64 \mathrm{~cd}$ \\
\hline Soil mean & $65 b$ & $43 c$ & $62 b$ & $85 \mathrm{a}$ & $\begin{array}{l}\text { Treat. 1.s.d. } 6 \\
\text { Soil 1.s.d. } 5\end{array}$ \\
\hline \multicolumn{6}{|c|}{2012} \\
\hline W-W-W-W & 37 & 23 & 40 & 67 & $42 \mathrm{~cd}$ \\
\hline \multicolumn{6}{|c|}{ Second-year effects } \\
\hline W-C-W-W & 41 & 28 & 45 & 70 & $46 a b c$ \\
\hline W-R-W-W & 43 & 28 & 39 & 67 & $44 \mathrm{bcd}$ \\
\hline W-DPR-W-W & 38 & 27 & 36 & 65 & $41 d$ \\
\hline W-Pa-W-W & 36 & 33 & 49 & 75 & $48 \mathrm{ab}$ \\
\hline W-L-W-W & 44 & 34 & 49 & 69 & $49 \mathrm{a}$ \\
\hline \multicolumn{6}{|c|}{ Third-year effects } \\
\hline FP-W-W-W & 41 & 27 & 45 & 62 & $44 \mathrm{bcd}$ \\
\hline $\mathrm{R}-\mathrm{W}-\mathrm{W}-\mathbf{W}$ & 39 & 29 & 39 & 64 & $43 \mathrm{~cd}$ \\
\hline DPR-W-W-W & 35 & 25 & 38 & 67 & $41 d$ \\
\hline $\mathrm{Pa}-\mathrm{W}-\mathrm{W}-\mathbf{W}$ & 42 & 31 & 46 & 64 & $46 a b c$ \\
\hline Soil mean & $40 \mathrm{c}$ & $28 \mathrm{~d}$ & $43 b$ & $67 \mathrm{a}$ & $\begin{array}{l}\text { Treat. 1.s.d. } 5 \\
\text { Soil 1.s.d. } 3\end{array}$ \\
\hline
\end{tabular}

$\mathrm{N}$-limited yield on all four soil types. Where the wheat yield potential was modelled using actual starting water with no limitation of $\mathrm{N}$, a yield gap of $0.6 \mathrm{tha}^{-1}$ remained on the midtop soil type and $0.1 \mathrm{tha}^{-1}$ on the swale (Fig. 3). In 2012, there were yield gaps in the order of $0.3-0.5 \mathrm{tha}^{-1}$ between wheat following 2010 lupin and the potential yield based on the starting water and $\mathrm{N}$ conditions of these treatments in all soils except the mid-bottom, which aligns with the loss of disease break effects in the second year after growing lupin. There was a further yield gap of $0.1-0.3 \mathrm{tha}^{-1}$ in these three soils when $\mathrm{N}$ was not limited.
Table 8. Pre-sowing soil mineral nitrogen $\left(\mathrm{kg} \mathrm{Nha}^{-1} \mathrm{~m}^{-1}\right.$ depth) in 2010-12 following breaks in 2009 and 2010 with the crop sequence for 2009-12 shown on the left and the crop for which mineral $N$ is presented shown in bold

$\mathrm{W}$, Wheat; FP, field pea; $\mathrm{R}$, rye; DPR, dual purpose hay and grain rye; $\mathrm{Pa}$, pasture; $\mathrm{C}$, canola; L, lupin. Within a season, predicted treatment means, or soil means, followed by the same letter are not significantly different at $P=0.05$

\begin{tabular}{|c|c|c|c|c|c|}
\hline Crop sequence & Dune & Crest & Mid-slope & Swale & Treatment mean \\
\hline \multicolumn{6}{|c|}{2009} \\
\hline W-W-W-W & 38 & & 32 & 82 & \\
\hline \multicolumn{6}{|c|}{2010} \\
\hline $\mathrm{W}-\mathbf{W}-\mathrm{W}-\mathrm{w}$ & 57 & 47 & 69 & 95 & $67 \mathrm{bc}$ \\
\hline \multicolumn{6}{|c|}{ First-year effects } \\
\hline $\mathrm{FP}-\mathbf{W}-\mathrm{W}-\mathrm{W}$ & 65 & 59 & 67 & 101 & $73 \mathrm{ab}$ \\
\hline $\mathrm{R}-\mathbf{W}-\mathrm{W}-\mathrm{W}$ & 42 & 23 & 69 & 91 & $56 \mathrm{c}$ \\
\hline $\mathrm{Pa}-\mathbf{W}-\mathrm{W}-\mathrm{W}$ & 69 & 64 & 94 & 111 & $84 \mathrm{a}$ \\
\hline & $58 r$ & $48 \mathrm{~s}$ & & 1007 & $\begin{array}{l}\text { Treat. 1.s.d. } 12 \\
\text { Soil l.s.d.11 }\end{array}$ \\
\hline \multicolumn{6}{|c|}{2011} \\
\hline W-W-W-W & 73 & 83 & 82 & 122 & $90 \mathrm{~b}$ \\
\hline \multicolumn{6}{|c|}{ First-year effects } \\
\hline $\mathrm{W}-\mathrm{C}-\mathbf{W}-\mathrm{W}$ & 92 & 74 & 129 & 104 & $100 \mathrm{~b}$ \\
\hline W-R-W-W & 107 & 63 & 127 & 104 & $100 \mathrm{~b}$ \\
\hline W-Pa-W-W & 133 & 81 & 119 & 130 & $116 a b$ \\
\hline W-L-W-W & 117 & 112 & 142 & 150 & $130 \mathrm{a}$ \\
\hline \multicolumn{6}{|c|}{ Second-year effects } \\
\hline $\mathrm{FP}-\mathrm{W}-\mathbf{W}-\mathrm{W}$ & 90 & 78 & 108 & 102 & $94 b$ \\
\hline R-W-W-W & 102 & 68 & 109 & 104 & $97 b$ \\
\hline $\mathrm{Pa}-\mathrm{W}-\mathbf{W}-\mathrm{W}$ & 91 & 139 & 114 & 112 & $114 \mathrm{ab}$ \\
\hline & & & & & Treat. 1.s.d. 27 \\
\hline Soil mean & $101 \mathrm{ab}$ & $87 \mathrm{~b}$ & $117 \mathrm{a}$ & $116 a b$ & Soil 1.s.d. 30 \\
\hline \multicolumn{6}{|c|}{2012} \\
\hline W-W-W-W & 127 & 136 & 161 & 135 & \\
\hline \multicolumn{6}{|c|}{ Second-year effects } \\
\hline $\mathrm{W}-\mathrm{C}-\mathrm{W}-\mathbf{W}$ & 127 & 121 & 153 & 133 & \\
\hline W-R-W-W & 125 & 138 & 167 & 113 & \\
\hline $\mathrm{W}-\mathrm{Pa}-\mathrm{W}-\mathbf{W}$ & 122 & 137 & 154 & 132 & \\
\hline W-L-W-W & 122 & 138 & 142 & 138 & \\
\hline Soil mean & $125 \mathrm{c}$ & $134 \mathrm{~b}$ & $155 \mathrm{a}$ & $130 \mathrm{bc}$ & Soil 1.s.d. 9 \\
\hline
\end{tabular}

\section{Discussion \\ Quantifying the break effect on continuous cereal production}

Supporting the outcomes of the regression analysis of the relationship between yields of continuous wheat and wheat following break crop (Fig. 1), Angus et al. (2008) suggested that the break effect should be expressed as a quantity rather than a percentage because the yield increase is not generally proportional to yield with benefits in the range of $0.9-1.8 \mathrm{tha}^{-1}$ extra yield. In our case, the benefit was $\sim 0.7 \mathrm{tha}^{-1}$ in the first year and at least $1 \mathrm{tha}^{-1}$ over a 3-year period. The data from this experiment were included in a combined analysis with experimental data from Hopetoun in the Victorian Mallee, and with the larger dataset we were able to demonstrate that the firstyear after-break benefit of a brassica was in the order of $0.5+0.9$ continuous wheat yield $\left(\mathrm{tha}^{-1}\right)$ and for legume $1.1+0.9$ continuous wheat yield $\left(\mathrm{tha}^{-1}\right)$ (Kirkegaard et al. 2014). The level of first-year benefit observed in the Mallee environment at Karoonda was more closely aligned with the $0.3-0.6 \mathrm{tha}^{-1}$ of 
Table 9. Surface $(0-10 \mathrm{~cm})$ pre-sowing $\mathrm{N}$ supply potential $\left(\mathrm{kg} \mathrm{ha}^{-1}\right.$ season ${ }^{-1}$ ) in 2010-12 following breaks in 2010 with the crop sequence for 2009-12 shown on the left and the crop for which $\mathrm{N}$ supply potential is presented shown in bold

W, Wheat; C, canola; R, rye; Pa, pasture; L, lupin. Within a season, predicted means followed by the same letter are not significantly different at $P=0.05$

\begin{tabular}{|c|c|c|c|c|}
\hline Crop sequence & Dune & Mid-slope & Swale & Treatment mean \\
\hline \multicolumn{5}{|c|}{2010} \\
\hline \multirow[t]{3}{*}{$\mathrm{W}-\mathbf{W}-\mathrm{W}-\mathrm{W}$} & $22 b$ & $22 b$ & $33 \mathrm{a}$ & \\
\hline & & & & Soil 1.s.d. 7 \\
\hline & \multicolumn{3}{|c|}{2011 first-year effects } & \\
\hline W-W-W-W & $27 \mathrm{j}$ & $29 \mathrm{ij}$ & 46de & \\
\hline $\mathrm{W}-\mathrm{C}-\mathbf{W}-\mathrm{W}$ & $41 \mathrm{efg}$ & $43 \mathrm{defg}$ & $75 \mathrm{a}$ & \\
\hline W-R-W-W & $33 \mathrm{hij}$ & $33 \mathrm{hij}$ & $54 \mathrm{c}$ & \\
\hline W-Pa-W-W & $36 \mathrm{ghi}$ & $50 \mathrm{~cd}$ & $74 \mathrm{a}$ & \\
\hline \multirow[t]{3}{*}{$\mathrm{W}-\mathrm{L}-\mathbf{W}-\mathrm{W}$} & $38 \mathrm{fgh}$ & 44def & $65 \mathrm{~b}$ & \\
\hline & & & & Soil $\times$ treat. 1.s.d. 8 \\
\hline & \multicolumn{3}{|c|}{2012 second-year effects } & \\
\hline $\mathrm{W}-\mathrm{W}-\mathrm{W}-\mathbf{W}$ & 30 & & 58 & $44 \mathrm{c}$ \\
\hline $\mathrm{W}-\mathrm{C}-\mathrm{W}-\mathbf{W}$ & 39 & & 67 & $53 b$ \\
\hline W-R-W-W & 36 & & 70 & $53 b$ \\
\hline $\mathrm{W}-\mathrm{Pa}-\mathrm{W}-\mathbf{W}$ & 46 & & 81 & $63 \mathrm{a}$ \\
\hline \multirow[t]{2}{*}{ W-L-W-W } & 50 & & 71 & $56 \mathrm{ab}$ \\
\hline & & & & Treat. 1.s.d. 8 \\
\hline Soil mean & $38 \mathrm{~b}$ & & $69 \mathrm{a}$ & Soil 1.s.d. 5 \\
\hline
\end{tabular}

benefit reviewed by Seymour et al. (2012) in the Western Australian environment. Seymour et al. (2012) suggested that leguminous breaks provide more consistent break effects of a greater magnitude, which is supported by our results; in particular, the break effect of legumes had greater longevity. However, brassica breaks were evaluated in only one instance, and in the first season after the break, the magnitude of the break effect from canola was similar to that of legumes.

Given the potential to generate an extra tonne of wheat production in a semi-arid environment, the inclusion of breaks is likely to play an important role in closing the gap between yield attained and yield potential. Our analysis of the wheat yield potential on these soil types under the conditions of continuous wheat $v$. a lupin break showed that the inclusion of the legume break played a significant role in closing the gap between actual and potential yields in the first season after the break (Fig. 3). An N-limited gap in yield in two of the soil types remained, demonstrating the importance of $\mathrm{N}$ to productivity in this environment. In the second year after the break, plots sown to wheat for the second year after a lupin break did not reach the yield potential modelled according to the starting $\mathrm{N}$ and water conditions. This coincided with a loss of disease break effect (Table 10), which prevented full utilisation of the soil water and $\mathrm{N}$ resources by the wheat crop. A small yield gap also remained, which model analysis suggested would be closed through access to further $\mathrm{N}$ resources (Fig. 3).

\section{Mechanisms controlling the break effect}

In semi-arid environments, increased $\mathrm{N}$ inputs have an important role in closing the gap between actual and potential yield (Sadras 2002). In a crop sequence, the nature of the crop residue affects nutrient decomposition and mineralisation processes because of changes in the quality and quantity of
Table 10. Effects of soil-borne disease measured using root rating score, infected crowns, number of crowns and internode length with the crop sequence for 2009-12 shown on the left and the crop for which disease effects are presented shown in bold

W, Wheat; R, rye; Pa, pasture; C, canola; L, lupin. Within a season and parameter, predicted means followed by the same letter are not significantly different at $P=0.05$; n.s., not significant

\begin{tabular}{|c|c|c|c|c|}
\hline Crop sequence & $\begin{array}{l}\text { Root } \\
\text { rating } \\
\text { score } \\
(1-5)\end{array}$ & $\begin{array}{l}\text { Infected } \\
\text { crowns } \\
\text { (\% of } 20 \\
\text { plants) }\end{array}$ & $\begin{array}{l}\text { Total no. } \\
\text { of crowns } \\
\text { (per } 20 \\
\text { plants) }\end{array}$ & $\begin{array}{c}\text { Internode } \\
\text { length } \\
(\mathrm{cm})\end{array}$ \\
\hline \multicolumn{5}{|c|}{2010 first-year effects } \\
\hline $\mathrm{W}-\mathbf{W}-\mathrm{W}-\mathrm{W}$ & 2.98 & 65 & $5.4 \mathrm{~b}$ & 8.3 \\
\hline $\mathrm{R}-\mathbf{W}-\mathrm{W}-\mathrm{W}$ & 2.99 & 60 & $5.5 \mathrm{~b}$ & 10.2 \\
\hline $\mathrm{Pa}-\mathbf{W}-\mathrm{W}-\mathrm{W}$ & 2.72 & 58 & $6.1 \mathrm{a}$ & 6.7 \\
\hline Treatment 1.s.d. & n.s. & n.s. & 0.5 & n.s. \\
\hline Dune & - & - & - & - \\
\hline Mid-slope & $3.13 \mathrm{a}$ & 60 & 5.3 & $15.8 \mathrm{a}$ \\
\hline Swale & $2.33 b$ & 54 & 6.0 & $0.8 \mathrm{~b}$ \\
\hline Soil 1.s.d. & 0.27 & n.s. & n.s. & 4.5 \\
\hline \multicolumn{5}{|c|}{2011 first-year effects } \\
\hline $\mathrm{W}-\mathrm{W}-\mathbf{W}-\mathrm{W}$ & 1.04 & $22 \mathrm{c}$ & 5.5 & $1.6 \mathrm{ab}$ \\
\hline $\mathrm{W}-\mathrm{C}-\mathbf{W}-\mathrm{W}$ & 1.02 & $23 b$ & 5.5 & $1.6 \mathrm{ab}$ \\
\hline W-R-W-W & 1.14 & $26 \mathrm{a}$ & 5.3 & $1.7 \mathrm{a}$ \\
\hline W-Pa-W-W & 0.98 & $22 \mathrm{c}$ & 5.7 & $1.2 \mathrm{~b}$ \\
\hline $\mathrm{W}-\mathrm{L}-\mathbf{W}-\mathrm{W}$ & 0.84 & $19 \mathrm{~d}$ & 5.6 & $1.6 \mathrm{ab}$ \\
\hline Treatment 1.s.d. & n.s. & 0.2 & n.s. & 0.4 \\
\hline Dune & $0.73 b$ & $15 \mathrm{c}$ & $5.3 b$ & $1.7 \mathrm{a}$ \\
\hline Mid-slope & $0.89 \mathrm{~b}$ & $20 \mathrm{~b}$ & $5.4 \mathrm{~b}$ & $1.9 \mathrm{a}$ \\
\hline Swale & $1.40 \mathrm{a}$ & $31 \mathrm{a}$ & $5.9 \mathrm{a}$ & $1.1 \mathrm{~b}$ \\
\hline Soil 1.s.d. & 0.2 & 5 & 0.3 & 0.3 \\
\hline \multicolumn{5}{|c|}{2012 second-year effects } \\
\hline $\mathrm{W}-\mathrm{W}-\mathrm{W}-\mathbf{W}$ & $* \mathrm{~A}$ & 32 & 2.6 & 2.1 \\
\hline $\mathrm{W}-\mathrm{C}-\mathrm{W}-\mathbf{W}$ & & 26 & 2.5 & 1.8 \\
\hline W-R-W-W & & 34 & 2.7 & 1.8 \\
\hline W-P-W-W & & 36 & 1.9 & 1.8 \\
\hline W-L-W-W & & 32 & 2.6 & 2.0 \\
\hline Treatment 1.s.d. & & n.s. & n.s. & n.s. \\
\hline Dune & & $27 b$ & $2.1 \mathrm{~b}$ & $2.5 \mathrm{a}$ \\
\hline Mid-slope & & - & - & - \\
\hline Swale & & $39 \mathrm{a}$ & $2.9 \mathrm{a}$ & $1.3 \mathrm{~b}$ \\
\hline Soil 1.s.d. & & 6 & 0.4 & 0.4 \\
\hline
\end{tabular}

${ }^{\text {A }}$ See Fig. 2 for significant interaction between treatment and soil type.

organic inputs, modifying the associated microbiology (Gupta et al. 2011). There are several examples of the contribution of legume crops to increased levels of $\mathrm{N}$ supply in subsequent crops, with an average of $37-47 \mathrm{~kg} \mathrm{ha}^{-1}$ of additional nitrate-N (Angus et al. 2006; Kirkegaard et al. 2008). Angus et al. (2008) suggest that the $\mathrm{N}$ benefit supplied by legumes provides $0.5 \mathrm{tha}^{-1}$ of the $0.9-1.8 \mathrm{tha}^{-1}$ break effect.

In most of the rainfed cropping regions of southern Australia, soil moisture and availability of $\mathrm{C}$ are the major factors influencing microbial activity and biological processes involved in nutrient mineralisation (Gupta et al. 2011). Larger amounts of crop residues (C inputs) produced from the 2010 crops, combined with regular rainfall during summer, would have also facilitated higher microbial activities and nutrient mineralisation, improving overall plant nutrition. This is supported by the higher NSP values at sowing in 2011 than 


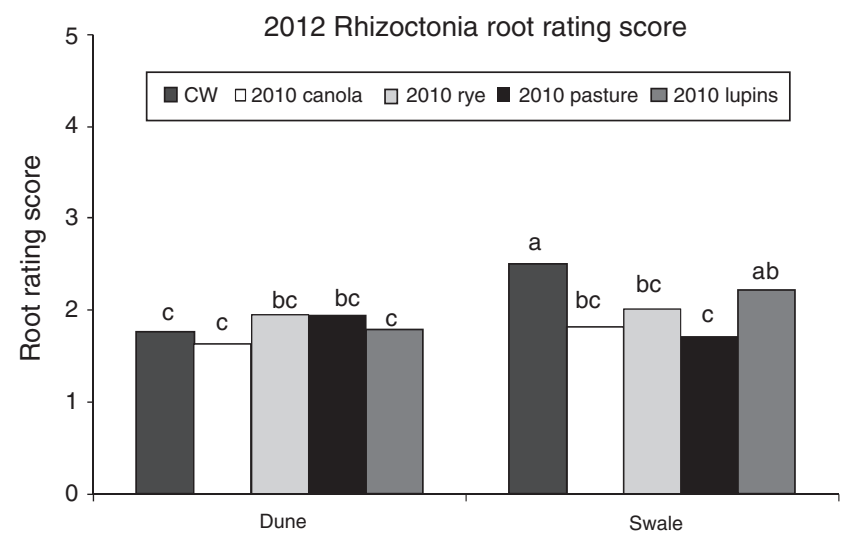

Fig. 2. Rhizoctonia root rating score at 7 weeks after sowing in the 2012 growing season on the dune and swale in response to different crop types grown in $2010(P<0.05$; 1.s.d. soil type $\times$ treat $=0.42)$. Columns with the same letter are not significantly different at $P=0.05$.
2010 (Table 9). Our estimation of NSP (Table 9) at the beginning of a crop season included both the $\mathrm{N}$ in microbial biomass and the potential of that microbial population for mineralisation, which depends on the quantity and quality of crop residues and the quality of soil organic matter (Gupta et al. 1994). Our observation of higher NSP following legume crops could mostly be attributed to the quality of crop residues, although changes in the microbial communities following legume crops would also have contributed to the shift in balance between mineralisation and immobilisation. Legume residues tend to have a higher $\mathrm{N}$ content (lower $\mathrm{C}: \mathrm{N}$ ratio) than cereal residues, resulting in higher levels of net $\mathrm{N}$ mineralisation after both grain and pasture legumes (Crews and Peoples 2005).

Peoples et al. (2009) indicated that $<30 \%$ of the legume $\mathrm{N}$ is taken up by the subsequent cereal crop, and the longevity of the effect will depend upon the amount of dry matter production and the contribution of $\mathrm{N}$ from legumes $v$. soil origin. Our findings clearly show that the N-derived benefits of legumes in

Table 11. Pre-sowing plant available water $\left(\mathrm{PAW}, \mathrm{mm} \mathrm{m}^{-1}\right.$ ) and water use efficiency (WUE, $\mathrm{kg} \mathrm{ha}^{-1} \mathrm{~mm}^{-1}$ ) in $2010-12$ following breaks in 2009 and 2010 with the crop sequence for 2009-12 shown on the left and the crop for which PAW and WUE are presented shown in bold

W, Wheat; FP, field pea; R, rye; Pa, pasture; C, canola; L, lupin. Within a season, predicted means followed by the same letter are not significantly different at $P=0.05$

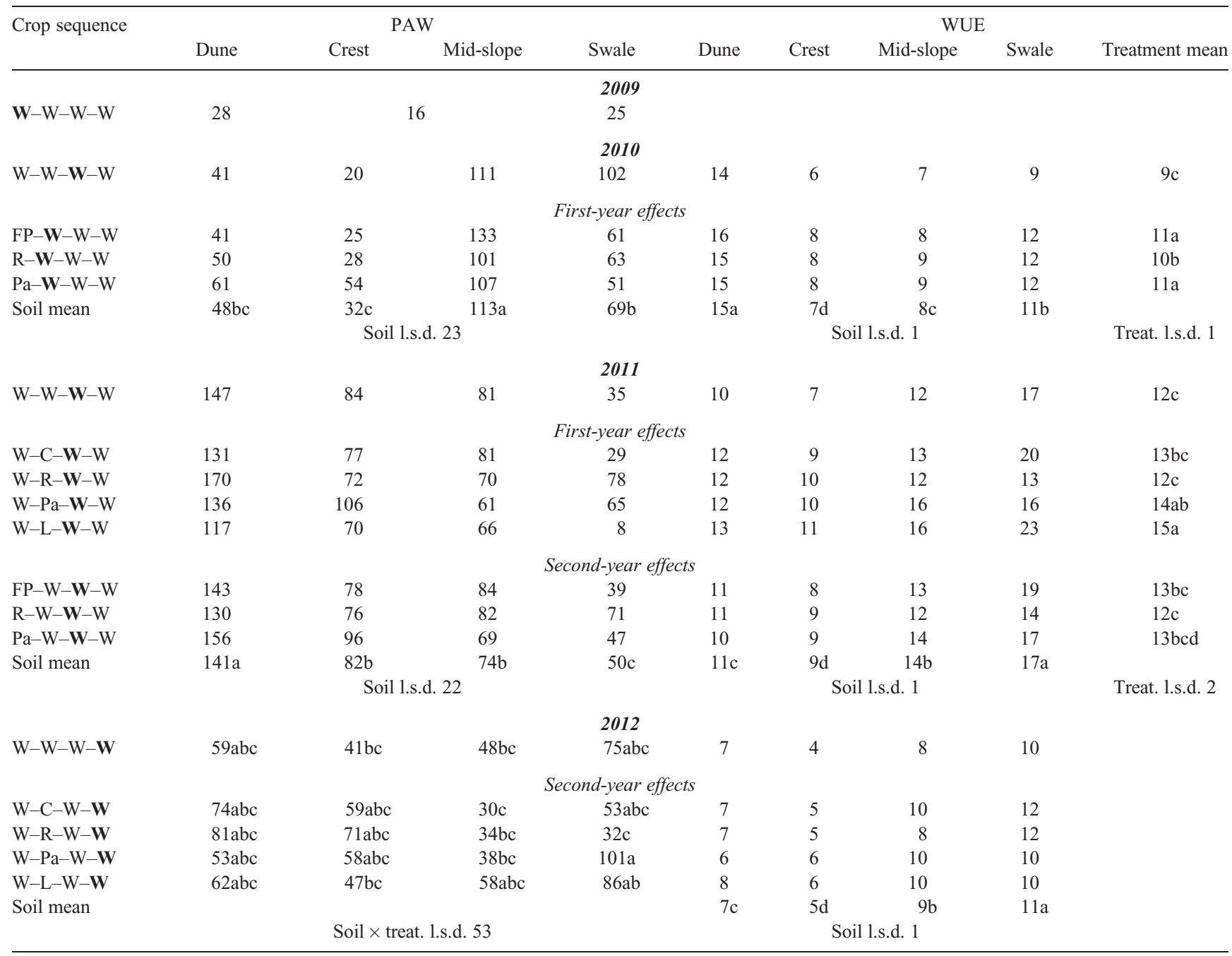



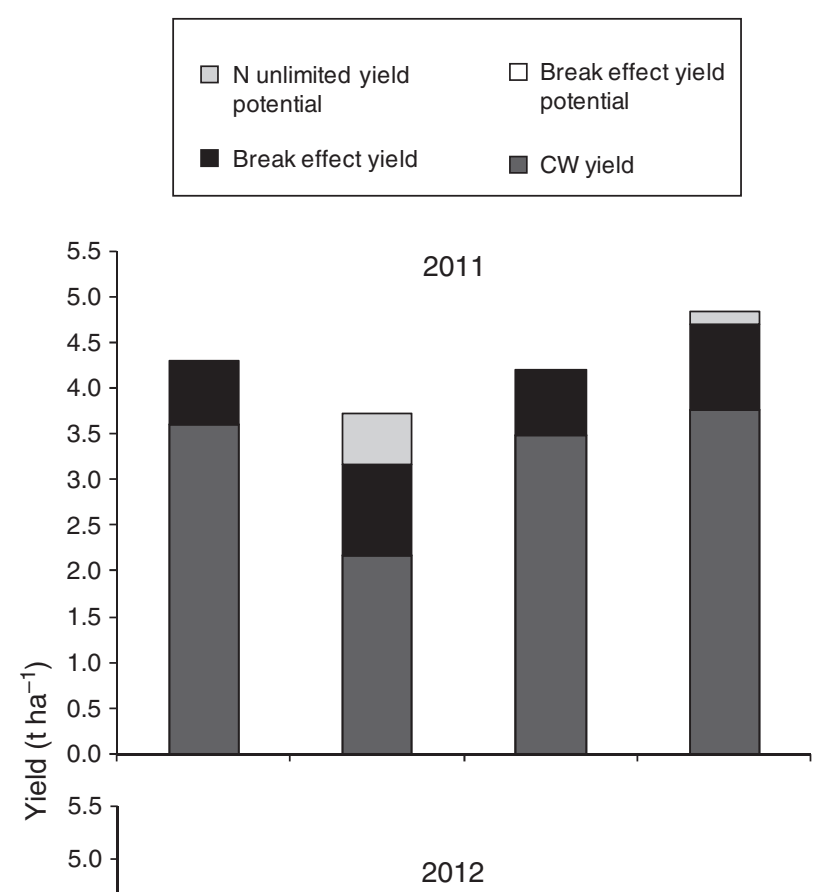

Fig. 3. An illustration of the role of the 2010 lupin break crop in closing the 2011 and 2012 wheat yield gap by comparing the yield attained in a continuous wheat treatment (CW yield), the yield attained with the 2010 lupin break effect (break effect yield), the potential yield for the break effect treatment using the experimental starting water and nitrogen $(\mathrm{N})$ (break effect yield potential) and the $\mathrm{N}$-unlimited yield potential using experimental starting water ( $\mathrm{N}$ unlimited yield potential) on each of the four soil types.

the sequence persisted into the second year. When legume crop residues decompose, they become part of the soil organic matter pools (e.g. particulate organic matter) and their contribution to $\mathrm{N}$ supply is likely to persist for more than one season (Ladd et al. 1986). The build-up of $\mathrm{N}$ in soil organic matter (i.e. decrease in $\mathrm{C}: \mathrm{N}$ ratio) from legumes in the rotation is especially important in sandy and sandy-loam areas in lower organic matter, semi-arid soils (Gupta et al. 2011).

Because of the low levels of biologically available $\mathrm{C}$ in these soils, crops that add large amounts of plant biomass such as cereal rye can improve microbial populations (biomass) and activity, which in turn support greater $\mathrm{N}$ mineralisation in subsequent seasons. At Karoonda, in all of the soils, cereal rye produced high levels of plant biomass (Table 5) and thus provided a large amount of $\mathrm{C}$ inputs. However, a lower $\mathrm{N}$ concentration (wider $\mathrm{C}: \mathrm{N}$ ratio) in the cereal rye residues means that the $\mathrm{N}$ required for microbial assimilation and subsequent release would have come from soil organic matter, and hence NSP benefits would have been lower than with N-rich legumes. Although the firstyear NSP benefits from cereal rye $\left(4-8 \mathrm{~kg} \mathrm{~N} \mathrm{ha}^{-1}\right.$ season $\left.^{-1}\right)$ were of smaller magnitude than from a legume $\left(11-20 \mathrm{~kg} \mathrm{Nha}^{-1}\right.$ season $^{-1}$ ) (Table 9), the addition of higher total $\mathrm{C}$ inputs can have beneficial effects through an increase in overall biological activity, in particular in the lower organic matter soils in the Mallee where $\mathrm{C}$ inputs from crops are a key source of $\mathrm{C}$ for soil biota (Gupta and Roget 2004).

Canola has been shown to modify the composition of the general microbial community, resulting in changes in biological functions such as nitrification and in accelerated $\mathrm{N}$ mineralisation (Ryan et al. 2006; Kirkegaard et al. 2008; Gupta et al. 2011). The effect of canola on NSP was greater in 2011 (first-year effect) than in 2012 (second-year effect) (Table 9). Canola residues have a wider $\mathrm{C}: \mathrm{N}$ ratio, similar to cereal residues; hence, soil organic matter would be the major source of $\mathrm{N}$ for mineralisation. Therefore, we hypothesise that because the soils in these experiments are low in soil organic matter (Table 2), they probably are capable of supporting canola-derived extra $\mathrm{N}$ mineralisation for only one season.

Canola has been reported to reduce the populations of soilborne necrotrophic pathogens such as $R$. solani AG8 and Gaeumannomyces graminis var. tritici, thereby decreasing the impacts of disease in following cereal crops (Kirkegaard et al. 2008; Gupta et al. 2010). The incidence and severity of rhizoctonia bare patch (caused by $R$. solani AG8) depends on the amount of inoculum, composition and activity of the soil biology community (inherent suppressive activity), and available soil $\mathrm{N}$ over the non-crop period. In experiments across southern Australia, Gupta et al. (2012a) found that R. solani AG8 inoculum levels generally increased within cereal crops, whereas noncereal crops with good control of grass weeds either reduced, or caused no change in, DNA levels of $R$. solani AG8. In the experiments at Karoonda, inoculum build-up was consistently lowest in the brassica crop, canola (Gupta et al. 2012b). Lower levels of rhizoctonia disease in the wheat crop following noncereal crops, in particular brassica crops, can be mostly attributed to the reduced inoculum levels of the pathogen. Although DNA levels of $R$. solani AG8 generally increase within cereal crops, multiple rainfall events during summer can reduce inoculum levels from high to low disease risk (Gupta et al. 2012a). At Karoonda, regular rainfall events during the summer of 2010-11 would have reduced the inoculum loads by the time of sowing, resulting in lower levels of disease incidence in the 2011 wheat crop, and there were no significant differences in the disease incidence after different crops. The effect of environment, e.g. rainfall, on inoculum levels at sowing and subsequent disease incidence is clear from the difference in percentage crown root infection in the 2010 wheat crop (average 57\%) compared with the 2011 crop (average 22\%).

The effect of lower disease incidence after canola than after cereal rye (on swale and mid-slope) highlights the importance of cereal disease control from breaks in the Mallee soils. Although 
the root and stubble $\mathrm{C}$ from the cereal rye crop may increase microbial biomass and microbial activity (Gupta et al. 2012b), cereal rye did not reduce rhizoctonia disease in the following wheat crop (Table 10). Rhizoctonia disease reduces effective root volume; therefore, even low levels of disease can have negative impact on the ability of plants to access water and nutrients. In our experiments, $\mathrm{N}$ availability was generally better after legumes (pasture and grain legumes), as indicated by higher soil mineral $\mathrm{N}$ levels and $\mathrm{N}$ mineralisation potentials, which would have provided a compensatory effect from the reduced root volume due to rhizoctonia disease (Rovira 1990). This improved ability of plants to tolerate root damage would also reduce the crop area lost to patches of poor growth and thus lower yield loss. In our experiments, the beneficial effect of legume crops on $\mathrm{N}$ supply potential was also seen in the second crop season, although it was lower than that in the first season after breaks. Gupta et al. (2012a) reported that the effect of non-cereal crops on inoculum levels $R$. solani lasted for one crop season only and inoculum levels would increase after a cereal crop.

The effects of breaks in the sequences on subsequent PAW and resulting cereal WUE are variable and strongly dependent on prevailing seasonal conditions during the fallow. In our experiment, there were no significant effects of growing a break on PAW for sowing the subsequent crop. There are instances in the literature where brassica breaks have drawn down extra water and decrease yield compared with continuous wheat, and instances of legumes having a lower water use and therefore providing a water benefit (Kirkegaard et al. 2008; Garofalo et al. 2009; Anderson 2011; Seymour et al. 2012).

Anderson (2011) suggested that some break effects increase WUE because the crop produces more yield with the same water (e.g. legume effect supplying extra N), and these are called synergistic effects, whereas other break effects increase yield capacity (e.g. where canola has resulted in increased root exploration as a result of disease break) but also require more resources to produce the break effect. Given the lack of effect on sowing PAW and the strong evidence for increased supply of $\mathrm{N}$ via different mechanisms for all break types, a large component of the increase in WUE through the use of breaks in the sequence is likely derive from synergistic effects. For legume breaks, this synergistic effect is likely to be in part driven by the timing of legume-derived $\mathrm{N}$ supply, which has the potential to shift the distribution of water use in subsequent crops (Asseng et al. 1998b).

\section{Management of breaks in low-rainfall environments}

We have demonstrated that the inclusion of breaks to continuous cereal in the sequence can provide a substantial benefit to the production of wheat grain and that in the short term the three break types (legume, brassica and cereal) all provided increased NSP, whereas legume breaks were able to confer this advantage for a longer duration. Although the yields of the break options differ substantially across soil types and some are likely to be better a choice than others on a particular soil, the effect of different breaks on subsequent wheat yields did not differ reliably across soil types. In a low-rainfall environment where the growth of breaks is considered risky, the break advantage conferred by volunteer pasture with minimal management is of particular interest. Several relatively low-risk, low-cost management options (e.g. selective grass weed control, grazing management and fertilisation with phosphorus) are likely to increase the productivity of the legume component and potentially confer a greater break effect. This warrants further investigation.

Break effects in terms of cumulative extra wheat yield $\left(\mathrm{t} \mathrm{ha}^{-1}\right)$ over 2-3 years were less variable across soil types and seasons than break yields. In particular, the provision of secondyear break-effect benefits from legume breaks would appear to make the inclusion of a legume-based break an attractive proposition. Together with any weed control benefits, the economic decision to incorporate a break in the sequence should be driven by the ability of the cumulative extra tonne of wheat that is produced in the 2 years after the break to compensate for any loss in income in the year that the break crop is grown. As continuous cereal crops become more difficult and expensive to manage, the use of breaks from continuous cereals will likely become a more economically attractive option.

\section{Conclusions}

Break crops can provide benefits to the production of wheat in semi-arid Mallee environments. The magnitude of the cumulative break effect on three subsequent wheat crops is in the order of $1 \mathrm{tha}^{-1}$ of extra wheat production. Based on this study, growers can be more certain about the economic gains from the break effect on wheat yield across seasons and soil types than about the economic returns of the break crop in the year that it is grown. In a system where weeds were still manageable in the cereal phase, the source of the break effect was largely $\mathrm{N}$-derived but the process by which the $\mathrm{N}$ benefit was derived depended on the break type (legume $v$. brassica $v$. grass).

\section{Acknowledgements}

Funding for this work was from the Grains Research and Development Corporation (Project CSA00025 and CSE00048). Thanks to Damian Mowat, Stasia Kroker, Daniel Smith and Paul Adkins for technical support, to the Loller family for the provision of land, and to Jeff Braun and the Mallee Sustainable Farming Advisory Committee for additional advice. Thanks to James Hunt and Andrew Fletcher for comments on earlier versions of the manuscript.

\section{References}

Anderson RL (2011) Synergism: A rotation effect of improved growth efficiency. Advances in Agronomy 112, 205-226. doi:10.1016/B978-012-385538-1.00005-6

Angus JF, Kirkegaard JA, Peoples MB (2001) Rotation, sequence and phase: Research on crop and pasture systems. In 'Proceedings 10th Australian Agronomy Conference'. Hobart, Tas. (Australian Society of Agronomy/ The Regional Institute Ltd: Gosford, NSW) Available at: www.regional. org.au/au/asa/2001/plenary/4/angus.htm

Angus JF, Bolger TP, Kirkegaard JA, Peoples MB (2006) Nitrogen mineralisation in relation to previous crops and pastures. Australian Journal of Soil Research 44, 355-365. doi:10.1071/SR05138

Angus JF, Peoples MB, Kirkegaard JA, Ryan MH, Ohlander L (2008) The value of break crops for wheat. In 'Proceedings 14th Australian Agronomy Conference'. Adelaide, S. Aust. (Australian Society of Agronomy/The Regional Institute Ltd: Gosford, NSW) Available at: www.regional.org. $\mathrm{au} / \mathrm{au} / \mathrm{asa} / 2008 /$ concurrent/rotations/5786_angusjf.htm 
Asseng S, Keating BA, Fillery IRP, Gregory PJ, Bowden JW, Turner NC, Palta JA, Abrecht DG (1998a) Performance of the APSIM-wheat model in Western Australia. Field Crops Research 57, 163-179. doi:10.1016/ S0378-4290(97)00117-2

Asseng S, Fillery IRP, Gregory PJ (1998b) Wheat response to alternative crops on a duplex soil. Australian Journal of Experimental Agriculture 38, 481-488. doi:10.1071/EA97152

Blair GJ, Chinoim N, Lefroy RDB, Anderson GC, Crocker GJ (1991) A soil sulphur test for pastures and crops. Australian Journal of Soil Research 29, 619-626. doi:10.1071/SR9910619

Bowen GD, Rovira AD (1999) The rhizosphere and its management to improve plant growth. Advances in Agronomy 66, 1-102. doi:10.1016/ S0065-2113(08)60425-3

Carberry PS, Probert ME, Dimes JP, Keating BA, McCown RL (2002) Role of modelling in improving nutrient efficiency in cropping systems. Plant and Soil 245, 193-203. doi:10.1023/A:1020612416034

Colwell JD (1963) The estimation of phosphorus fertilizer requirements of wheat in Southern New South Wales by soil analysis. Australian Journal of Experimental Agriculture 3, 190-197. doi:10.1071/ EA9630190

Crews TE, Peoples MB (2005) Can the synchrony of nitrogen supply and crop demand be improved in legume and fertilizer-based agroecosystems? A review. Nutrient Cycling in Agroecosystems 72, 101-120. doi:10.1007/ s10705-004-6480-1

Dalgliesh NP, Foale MA (1998) 'Soil matters: monitoring soil water and nutrients in dryland farming.' (Agricultural Production Systems Research Unit: Toowoomba, Qld)

Díaz-Ambrona CH, Ines Minguez M (2001) Cereal-legume rotations in a Mediterranean environment: biomass and yield production. Field Crops Research 70, 139-151. doi:10.1016/S0378-4290(01)00132-0

Garofalo P, Di Paolo E, Rinaldi M (2009) Durum wheat (Triticum durum Desf.) in rotation with faba bean (Vicia faba var. minor L.): long-term simulation case study. Crop \& Pasture Science 60, 240-250. doi:10.1071/ CP08208

Gupta VVSR, Roget DK (2004) Understanding soil biota and biological functions: Management of soil biota for improved benefits to crop production and environmental health. In 'Soil biology in agriculture'. Tamworth, NSW. (Ed. R Lines-Kelly) pp. 1-7. (Tamworth Agricultural Institute: Tamworth, NSW)

Gupta VVSR, Roper MM, Kirkegaard JA, Angus JF (1994) Changes in microbial biomass and organic matter levels during the first year of modified tillage and stubble management practices on a red earth. Australian Journal of Soil Research 32, 1339-1354. doi:10.1071/ SR9941339

Gupta VVSR, McKay A, Diallo S, Smith D, Cook A, Kirkegaard J, OphelKeller K, Roget DK (2010) Temporal dynamics of Rhizoctonia solani AG8 inoculum in Australian soils. In 'Proceedings of the 6th Australian Soilborne Diseases Symposium'. 9-11 August 2010. (Ed. GR Stirling) (Horticulture Australia: Sydney)

Gupta VVSR, Rovira AD, Roget DK (2011) Principles and management of soil biological factors for sustainable rainfed farming systems. In 'Rainfed farming systems'. (Eds P Tow, I Cooper, I Partridge, C Birch) pp. 149-184. (Springer Science and Business Media: Berlin, Heidelberg)

Gupta VVSR, Llewellyn RS, McBeath TM, Kroker S, Davoren CW, McKay A, Ophel-Keller K, Whitbread AM (2012a) Break crops for disease and nutrient management in intensive cereal cropping. In 'Capturing opportunities and overcoming obstacles in Australian agronomy. Proceedings 16th Australian Agronomy Conference'. 14-18 October 2012, Armidale, NSW. (Ed. I Yunusa) (Australian Society of Agronomy/The Regional Institute Ltd: Gosford, NSW) Available at: www.regional.org.au/au/asa/2012/nutrition/7961_vadakattugupta.htm

Gupta VVSR, McKay A, Diallo S, Smith D, Cook A, Kirkegaard J, OphelKeller K, Davoren CW, Llewellyn R, Roget DK (2012b) Rhizoctonia solani AG8 inoculum levels in Australian soils are influenced by crop rotation and summer rainfall. In 'Proceedings of the 7th Australasian Soilborne Diseases Symposium'. 17-20 September 2012, Freemantle, W. Aust. (Australian Plant Pathology Society Inc.)

Hayman PT, Whitbread AM, Gobbett DL (2010) The impact of El Nino southern oscillation on seasonal drought in the southern Australian grainbelt. Crop \& Pasture Science 61, 528-539. doi:10.1071/CP09221

Hunt JR, Kirkegaard JA (2011) Re-evaluating the contribution of summer fallow rain to wheat yield in southern Australia. Crop \& Pasture Science 62, 915-929. doi:10.1071/CP11268

Isbell RF (1997) 'The Australian Soil Classification.' (CSIRO Publishing: Melbourne)

Keating PA, Carberry PS, Hammer GS, Probert ME, Robertson MJ, Holzworth D, Huth NI, Hargreaves JNG, Meinke H, Hochman Z, McLean G, Verburg K, Snow V, Dimes JP, Silburn M, Wang E, Brown S, Bristow KL, Asseng S, Chapman S, McCown RL, Freebairn DM, Smith CJ (2003) An overview of APSIM, a model designed for farming systems simulation. European Journal of Agronomy 18, 267-288. doi:10.1016/S1161-0301(02)00108-9

King PM (1981) Comparison of the methods for measuring severity of water repellence of sandy soils and assessment of some factors that affect its measurement. Australian Journal of Soil Research 19, 275-285. doi:10.1071/SR9810275

Kirkegaard JA, Ryan MH (2014) Magnitude and mechanisms of persistent crop sequence effects on wheat. Field Crops Research 164, 154-165. doi:10.1016/j.fcr.2014.05.005

Kirkegaard JA, Howe GN, Pitson G (2001) Agronomic interactions between drought and crop sequence. In 'Proceedings 10th Australian Agronomy Conference'. Hobart, Tas. (Australian Society of Agronomy/The Regional Institute Ltd: Gosford, NSW) Available at: www.regional. org.au/au/asa/2001/4/c/kirkegaard1.htm

Kirkegaard JA, Christen O, Krupinsky J, Layzell D (2008) Break crop benefits in temperate wheat production. Field Crops Research 107, 185-195. doi:10.1016/j.fcr.2008.02.010

Kirkegaard JA, Hunt JR, McBeath TM, Lilley JM, Moore A, Verburg K, Robertson M, Oliver Y, Ward PR, Milroy S, Whitbread AM (2014) Improving water productivity in the Australian Grains industry-a nationally coordinated approach. Crop \& Pasture Science 65, 583-601. doi:10.1071/CP14019

Ladd JN, Butler JHA, Amato M (1986) Nitrogen fixation by legumes and their role as sources of nitrogen for soil and crops. Biological Agriculture and Horticulture 3, 269-286. doi:10.1080/01448765.1986.9754475

Lawes RA, Renton M (2010) The land use sequence optimiser (LUSO): A theoretical framework for analysing crop sequences in response to nitrogen, disease and weed populations. Crop \& Pasture Science 61, 835-843. doi:10.1071/CP10026

McDonald HJ, Rovira AD (1985) Development of inoculation techniques for Rhizoctonia solani and its application to screening cereal cultivars for resistance. In 'Ecology and management of soil-borne plant pathogens'. (Eds CA Parker, AD Rovira, KJ Moore, PTW Wong, JF Kollmorgen) pp. 174-176. (American Phytopathological Society: St Paul, MN, USA)

Monjardino M, McBeath TM, Brennan L, Llewellyn RS (2013) Are farmers in low-rainfall cropping regions under-fertilising with nitrogen? A risk analysis. Agricultural Systems 116, 37-51. doi:10.1016/j.agsy.2012. 12.007

Noack SR, McLaughlin MJ, Smernik RJ, McBeath TM, Armstrong RD (2012) Crop residue phosphorus: speciation and potential bioavailability. Plant and Soil 359, 375-385. doi:10.1007/s11104-0121216-5

Nuttall JG, Armstrong RD (2010) Impact of subsoil physicochemical constraints on crops grown in the Wimmera and Mallee is reduced during dry seasonal conditions. Australian Journal of Soil Research 48, 125-139. doi:10.1071/SR09075 
Ophel-Keller K, McKay A, Hartley D, Herdina, Curran J (2008) Development of a routine DNA-based testing service for soilborne diseases in Australia. Australasian Plant Pathology 37, 243-253. doi:10.1071/AP08029

Peoples MB, Hauggaard-Nielsen H, Jensen ES (2009) The potential environmental benefits and risks derived from legumes in rotation. In 'Nitrogen fixation in crop production'. Agronomy Monograph 52. (Eds DW Emerich, HB Krishnan) pp. 349-383. (ASA: Madison, WI, USA)

Peverill KI, Sparrow LA, Reuter DJ (Eds) (1999) 'Methods of soil analysisan interpretation manual.' (CSIRO Publishing: Melbourne)

Probert ME, Dimes JP, Keating BA, Dalal RC, Strong WM (1998) APSIM's water and nitrogen modules and simulation of the dynamics of water and nitrogen in fallow systems. Agricultural Systems 56, 1-28. doi:10.1016/ S0308-521X(97)00028-0

Rab MA, Fisher PD, Armstrong RD, Abuzar M, Robinson NJ, Chandra S (2009) Advances in precision agriculture in south-eastern Australia. IV. Spatial variability in plant-available water capacity of soil and its relationship with yield in site-specific management zones. Crop \& Pasture Science 60, 885-900. doi:10.1071/CP08350

Rayment GE, Lyons DJ (2011) 'Soil chemical methods: Australasia.' (CSIRO Publishing: Melbourne)

Robertson MJ, Llewellyn RS, Mandel R, Lawes RA, Bramley RGV, Swift LMN, O'Callagahan C (2012) Adoption of variable rate fertiliser application in the Australian grains industry: status, issues and prospects. Precision Agriculture 13, 181-199. doi:10.1007/s11119011-9236-3

Roper MM, Milroy SP, Poole ML (2012) Green and brown manures in dryland wheat production systems in Mediterranean-type environments. Advances in Agronomy 117, 275-313. doi:10.1016/B978-0-12-3942784.00005-2

Rovira AD (1990) The impact of soil and crop management practices on soil-borne root diseases and wheat yields. Soil Use and Management 6, 195-200. doi:10.1111/j.1475-2743.1990.tb00835.x

Ryan MH, Kirkegaard JA, Angus JF (2006) Brassica crops stimulate soil mineral N accumulation. Australian Journal of Soil Research 44, 367-377. doi:10.1071/SR05143
Sadras V (2002) Interaction between rainfall and nitrogen fertilisation of wheat in environments prone to terminal drought: economic and environmental risk analysis. Field Crops Research 77, 201-215. doi:10.1016/S0378-4290(02)00083-7

Sadras VO, Rodriguez D (2010) Modelling the nitrogen-driven trade-off between nitrogen utilisation efficiency and water use efficiency of wheat in eastern Australia. Field Crops Research 118, 297-305. doi:10.1016/ j.fcr.2010.06.010

Sadras VO, Roget DK (2004) Production and environmental aspects of cropping intensification in a semiarid environment of southeastern Australia. Agronomy Journal 96, 236-246.

Seymour M, Kirkegaard JA, Peoples MB, White PF, French RJ (2012) Break-crop benefits to wheat in Western Australia - insights from over three decades of research. Crop \& Pasture Science 63, 1-16. doi:10.1071/ CP11320

Sparling GP, Gupta VVSR, Zhu C (1993) Release of ninhydrin-reactive compounds during fumigation of soil to estimate microbial $\mathrm{C}$ and $\mathrm{N}$. Soil Biology \& Biochemistry 25, 1803-1805. doi:10.1016/0038-0717(93) 90186-F

Verburg K, Bond WJ, Hunt JR (2012) Fallow management in dryland agriculture: Explaining soil water accumulation using a pulse paradigm. Field Crops Research 130, 68-79. doi:10.1016/j.fcr.2012.02.016

Walkley A, Black IA (1934) An examination of the Degtjareff method for determining soil organic matter. A proposed modification of the chromic acid titration method. Soil Science 37, 29-38. doi:10.1097/ 00010694-193401000-00003

Whitbread A, Llewellyn R, Gobbett DL, Davoren B (2008) EM38 and cropsoil simulation modelling can identify differences in potential crop performance on typical soil zones in the Mallee. In 'Proceedings 14th Australian Agronomy Conference'. Adelaide, .S. Aust. (Australian Society of Agronomy/The Regional Institute Ltd: Gosford, NSW) Available at: www.regional.org.au/au/asa/2008/poster/agronomy-land scape/5823_whitbread.htm

Whitbread AM, Davoren CW, Gupta VVSR, Llewellyn R, Roget D (2015) Long-term cropping system studies support intensive and responsive cropping systems in the low-rainfall Australian Mallee. Crop \& Pasture Science 66, in press. 